'llu. Revista de Ciencias de las Religiones

ISSN: $1135-4712$

http://dx.doi.org/10.5209/ILUR.57421

\title{
O Virgo, templum Dei sanctum. Simbolismo del templo en imágenes de la Virgen María en los siglos XIV-XV según exégesis patrísticas y teológicas
}

\author{
José María Salvador González
}

Recibido: 10 de junio de 2016 / Aceptado: 3 de octubre de 2016

Resumen. De entre los elementos que han ido progresivamente complejizando las incontables representaciones de la Virgen María a lo largo de la historia, este artículo pretende destacar e interpretar conceptualmente uno de especial significación doctrinal en algunas imágenes marianas durante los siglos XIV y XV: el templo, en cuyo interior algunos artistas sitúan diversos episodios reales o simbólicos de María, desde su Nacimiento o su Anunciación hasta la Sacra Conversazione, por poner algunos ejemplos. Aun cuando a primera vista parece un mero ingrediente escenográfico u ornamental, sin mayor interés iconográfico, esa definida forma de templo trasluce en realidad profundos significados mariológicos y cristológicos. En ese orden de ideas, este ensayo se basa en una doble estrategia metodológica: ante todo, la de analizar algunas imágenes marianas que en dichos siglos incluyen la forma del templo, para ver qué papel juega en ellas semejante edificio religioso; en segundo lugar, la de descubrir las claves pertinentes para interpretar tales imágenes, analizando para ello específicos textos de Padres de la Iglesia y teólogos medievales que identifican con María la figura del «templo de Dios». Por tal motivo, tras una breve introducción al problema, el presente estudio se estructura en tres partes principales indisolublemente relacionadas: en la primera se analizan comparativamente doce pinturas marianas del referido período en las que la Virgen aparece situada en el interior de un templo; en la segunda se explayan las numerosas exégesis que, en concordante y sólida tradición patrística y teológica, identifican la figura analógica del templum Dei directamente con la Virgen María, o indirectamente con el cuerpo humano de Cristo engendrado en sus entrañas; sobre la base de ese doble análisis de imágenes y textos exegéticos, la tercera parte del artículo formula como sintética conclusión que la representación artística de un templo o un edificio eclesiástico en algunas imágenes marianas de los siglos XIV y XV constituye una convincente metáfora plástica de María y, en definitiva, de su virginal maternidad divina.

Palabras clave: Arte medieval; iconografía mariana; mariología; patrología; teología; Encarnación de Cristo; templum Dei.

\section{[en] O Virgo, templum Dei Sanctum. Symbolism of the temple in Virgin Mary's images in the fourteenth and fifteenth centuries according patristic and theological exegesis}

Abstract. Among the elements which have gradually been complicating the countless representations of the Virgin Mary throughout history, this paper seeks to highlight and interpret conceptually one of special doctrinal significance in some Marian images during the fourteenth and fifteenth centuries: the

\footnotetext{
1 Universidad Complutense de Madrid (España).

E-mail: jmsalvad@ucm.es
} 
temple, in whose interior some artists place some actual or symbolic episodes of Mary, from her birth or her Annunciation to the Sacra Conversazione, to give a few examples. Even though at first sight it looks as a mere scenographic or ornamental ingredient, without iconographic value, this precise shape of temple reveals in fact some profound Mariological and Christological meanings. In that order of ideas, this essay is based on a double methodological strategy: first and foremost, to analyze some Marian images which include in the aforementioned period the shape of a temple, in order to see what kind of role such a religious building plays in them; secondly, to discover the relevant keys for interpreting such images, by analyzing some specific texts of the Church Fathers and medieval theologians who identify with Mary the figure of the «temple of God». For this reason, after a brief introduction to the problem, the present study is structured into three main parts inextricably intertwined: in the first we comparatively analyze twelve Marian paintings of the fourteenth and fifteenth centuries in which the Virgin appears inside a temple; in the second we explain the many exegesis that, in a consistent and strong patristic and theological tradition, identify the analogy of the templum Dei directly with the Virgin Mary, or indirectly with the Christ's human body conceived in her womb; on the basis of this double analysis of images and exegetical writings, the third part of the paper states as a synthetic conclusion that the artistic representation of a temple or a church building in some Marian images of this period offers a compelling plastic metaphor of Mary and, ultimately, of her virginal divine motherhood. Keywords: Medieval Art; Marian iconography; Mariology; Patrology; theology; Annunciation; Incarnation of Christ; templum Dei.

Sumario. 1. Introduciendo el problema. 2. La representación del templo en imágenes de la Virgen María en los siglos XIV-XV. 2.1. Representaciones metonímicas del templo en imágenes marianas de los siglos XIV-XV. 2.2. Representaciones integrales del templo en imágenes marianas de los siglos XIV-XV. 3. Exégesis patrísticas y teológicas sobre la significación de María como templum Dei. 4. Conclusiones. 5. Fuentes y Bibliografía. 5.1. Fuentes. 5.2. Bibliografía.

Cómo citar: Salvador González, J. M. (2017), O Virgo, templum Dei sanctum. Simbolismo del templo en imágenes de la Virgen María en los siglos XIV-XV según exégesis patrísticas y teológicas, en 'Ilu. Revista de Ciencias de las Religiones 22, 359-398.

\section{Introduciendo el problema}

En el amplio y complejo universo de la iconografía cristiana ${ }^{2}$ ocupa un rango primordial la referida a la Virgen María. A su vez, la iconografía mariana se despliega en una ingente multitud de temas y motivos tipológicos, que -sin pretender enumerarlos en su totalidad - van desde los sucesos documentados de su vida real y los episodios fantasiosos que le atribuyen los escritos apócrifos y las leyendas populares, hasta las varias representaciones de su enaltecimiento como excelsa Madre de Dios y Reina de los Cielos, bajo la forma de la Asunción, la Coronación, la Virgen entronizada o la Sacra Conversazione, por aludir solo a algunas modalidades enaltecedoras, sin olvidar las numerosas variantes que configuran las diversas advocaciones marianas.

Interesa ahora poner en luz un elemento incluido a menudo en representaciones de María durante los siglos XIV y XV: un templo o iglesia, cuya estructura íntegra o parcial se afirma con relevancia en el contexto escénico en que el artista ambienta el tema representado, sea este el Nacimiento de María, la Anunciación, la Virgen en pie con su Niño en brazos, María entronizada como Sedes Sapientiae, la Sacra Conversazione, la Coronación de la Virgen o cualquier otra tipología mariana.

\footnotetext{
2 Para un abordaje de la iconografía cristiana en general, véanse Mâle 1988 (1898); Bréhier 1928; Toscano 1960; Mâle 1966 (1924); Mâle 1995; Réau 1955-59; Schiller 1968-70; Grabar 1979.
} 
Ahora bien, ese templo completo o fragmentario en imágenes de María pasa desapercibido a casi todos los comentaristas; otros expertos lo consideran un insignificante pormenor decorativo o escenográfico, cuyos aspectos estilísticos o formales se complacen a veces en describir; hay, por fin, algunos raros especialistas que, conscientes de la importancia de ese templo pintado, lo interpretan de modo injustificado - sin argumentos doctrinales- como una figura simbólica de María como Ecclesia, es decir, como Iglesia institucional. En ese último grupo de intérpretes figuran Erwin Panofsky, Marilyn Aronberg Lavin y Till-Holger Borchert, cuyos respectivos «argumentos» criticaremos en la subsiguiente parte de este artículo.

Por lo demás, ese paralelismo entre María y la Iglesia institucional ha sido puesto de relieve con gran rigor por Marie-Louise Thérel en su bien documentado libro Le triomphe de la Vierge-Église ${ }^{3}$. En esa brillante monografía, tomando pie en representaciones de la Dormición, la Asunción y la Coronación de María, y basándose en numerosos textos de Padres, teólogos y filósofos medievales, Thérel justifica esa identificación iconográfica entre la Virgen y la Iglesia como institución, tal como, a su juicio, puede apreciarse paradigmáticamente en el pórtico de Notre-Dame de Senlis.

Sin embargo, aun reconociendo en plena justicia la validez de esta interpretación de Marie-Louise Thérel en las obras de arte que analiza, nosotros -basándonos en incontables exégesis extraídas de Padres de la Iglesia y teólogos medievales, que expondremos en el siguiente apartado- ofreceremos en este artículo una nueva interpretación (no antitética, sino complementaria de la de Thérel) sobre el edificio eclesiástico que aparece plasmado en muchas imágenes marianas. De hecho, mientras la, indudablemente correcta, identificación de María como abstracta y universal Ecclesia o Iglesia institucional implica destacar en aquella su papel de corredentora, auxiliadora e intercesora de la Humanidad ${ }^{4}$, nosotros proponemos aquí -en sintonía con la tradición patrística ${ }^{5}$ y teológica ${ }^{6}$ - interpretar ese templo pintado en imágenes marianas como una metáfora visual del concreto e individual templum Dei, es decir, el hipostático templo que Dios Hijo se construyó para sí mismo en María con el fin de poder encarnarse en su designio de redimir a la Humanidad del pecado y procurarle la salvación eterna.

Ahora bien, como veremos a continuación, las exégesis de los autores eclesiásticos apuntan en dos proyecciones dogmáticas algo distintas, aunque esencialmente interrelacionadas: casi todos los Padres y teólogos, en efecto, identifican en forma directa ese templo de Dios con la Virgen María - toda ella como totalidad hipostática, o su vientre, como parte anatómica significativa-, al ser ella la predestinada por Dios

\footnotetext{
Thérel 1984.

4 Entre otros proyectos de investigación nos proponemos afrontar pronto la interpretación del templo pintado en imágenes marianas como metáfora visual de María como símbolo de la Ecclesia o Iglesia institucional, fundándonos en una larga tradición patrística y teológica, que amplía y profundiza los testimonios ofrecidos por M.-L. Thérel en su citado libro. Entre los Padres de la Iglesia y teólogos que consideran a María como figura simbólica de la Iglesia institucional podemos, por ejemplo, citar-sin entrar a analizarlos- a San Clemente de Alejandría, Orígenes, San Ambrosio, San Cromacio de Aquilea, San Agustín de Hipona, San Romano el Meloda, San Quodvultdeus, Aponio y San Buenaventura.

5 Para las fuentes patrísticas y teológicas son indispensables las dos grandes colecciones compiladas por J.-P. Migne: Patrologiae Cursus Completus. Series Latina, Paris, 1844-64, 221 vols. (citada como PL); Patrologiae Cursus Completus, Series Graeca, Paris, 1857-67, 166 vols. (citada como PG).

6 Para el estudio de las fuentes patrísticas y teológicas referidas a la mariología resulta de gran valor la colección de textos compilados en griego y latín por Sergio Álvarez Campos 1970-81, 7 vols.
} 
para hacer efectiva la concepción/encarnación del Redentor; a su vez, algunos exégetas identifican, de rebote o por vía indirecta, el templum Dei con el propio cuerpo humano de Cristo engendrado en las entrañas de María. Como quiera que sea, esas dos variantes interpretativas se condensan y subsumen en la tesis de que el templo pintado en algunas imágenes marianas bajomedievales constituye una metáfora plástica que permite visualizar la metáfora textual de la encarnación del Hijo de Dios en el vientre de la Virgen, o, dicho de otro modo, un símbolo de la virginal maternidad divina de María.

\section{La representación del templo en imágenes de la Virgen María en los siglos XIV-XV}

Sin importar cuál sea el tema o motivo devocional ni el episodio real o fabuloso de la vida de María que se esté representando en cualquier modalidad artística (pintura, escultura, miniatura), es frecuente observar en las imágenes marianas del mencionado período la presencia, más o menos sobresaliente, de un templo o un edificio con forma de iglesia. En tal sentido, hemos seleccionado, como perfectamente representativas de las distintas vertientes del tema en estudio, doce obras pictóricas producidas durante este período por prestigiosos artistas de Italia, Flandes, Francia y España.

El hecho de que, de entre las muchas imágenes artísticas que ilustran dicho motivo iconográfico del templo en escenas marianas, hayamos escogido esta docena de obras pictóricas se justifica por dos razones fundamentales: ante todo, por tratarse de los artistas y las obras que con mayor relevancia y eficacia manifiestan el contenido teológico de la figura del templo en el episodio concreto que narran; en segundo lugar, y sobre todo, porque la recurrencia y la similitud de enfoque con que el motivo iconográfico del templo en representaciones marianas se expresa durante esas dos centurias en países tan diversos como los cuatro mencionados, y por artistas de tan distinta sensibilidad como los que escogimos, permite suponer que las tesis mariológicas y cristológicas inherentes a la metáfora del templum Dei estaban por entonces suficientemente consolidadas en el universo cristiano, como consecuencia de una común herencia doctrinal, constituida por las coincidentes enseñanzas de los teólogos de la Iglesia en Oriente y en Occidente.

Ahora bien, dentro de esas representaciones de la Virgen con templo incluido, es posible distinguir dos tipologías iconográficas fundamentales, derivadas del especial tratamiento y de la relevancia específica que el artista otorga a dicho edificio: 1) la primera es la representación metonímica, conforme a la cual el templo en su conjunto viene sugerido solo mediante alguna de sus partes más características; 2) la segunda variante tipológica es la representación categórica de un templo al completo.

\subsection{Representaciones metonímicas del templo en imágenes marianas de los siglos XIV-XV}

Esta primera variante iconográfica, que figura en metonimia la totalidad del templo mediante alguna de sus partes más significativas, se ilustra a cabalidad en las siguientes siete obras de Pietro Lorenzetti, Paolo di Giovanni Fei, Govanni Bellini, Jan van Eyck, Rogier van der Weyden, Lluís Dalmau y Piero della Francesca. 


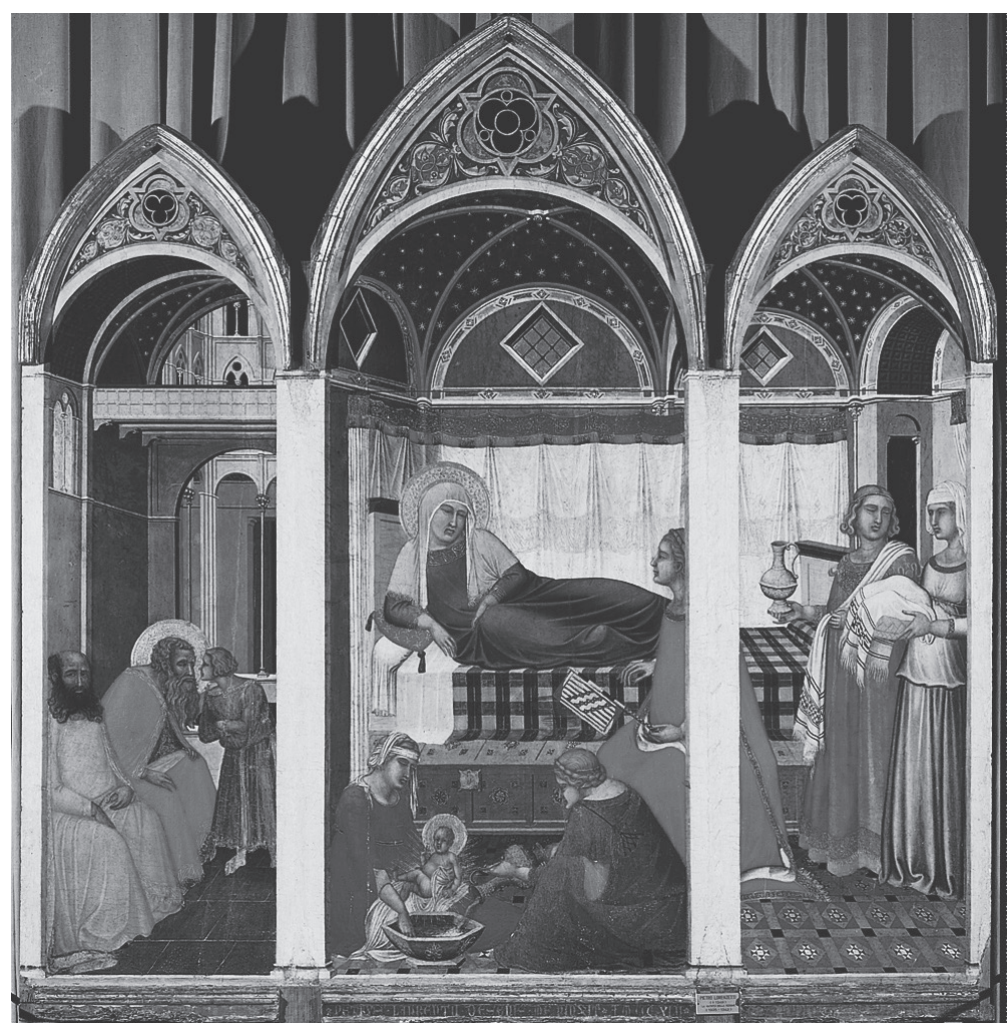

Fig. 1. Pietro Lorenzetti, El Nacimiento de la Virgen, 1335-42, Museo dell'Opera del Duomo, Siena. Imagen tomada de Wikimedia Commons https:/commons.wikimedia.org/ wiki/File:Nativity-of-the-virgin-pietro_lorenzetti_siena_museo_dell\%270pera_del_duomo.

jM (Última consulta: $10 / 0 \overline{5} / 2016)$

Pietro Lorenzetti ${ }^{7}$, en El Nacimiento de la Virgen, 1335-42, del Museo dell'Opera del Duomo en Siena ${ }^{8}$ (Fig. 1), plantea con gran originalidad este fantasioso episodio, que, como bien se sabe, se inspira en los escritos apócrifos sobre la infancia de María 9 . Dicho retablo -que, tras su encargo en 1335, fue concluido y entregado solo en 1342, como lo indica la firma y la fecha inscritas en letras doradas en el centro del borde inferior del marco: PETRUS LAURENTII DE SENIS ME PINXIT MCCCXLII- es un tríptico que el artista configura en una sólida unidad compositiva, abandonando así la tradicional separación e independencia entre los tres paneles de los trípticos. De hecho, aun fragmentando exteriormente el soporte de este retablo sienés en tres aparentes paneles -separados por las pilastras de encuadre y cada uno de ellos con

7 Sobre Pietro Lorenzetti véanse, entre otros, Volpe 1965; Smart 1978; Volpe 1989; Maginnis 1997; Maginnis 2001; Ragionieri 2009.

$8 \quad$ Petro Lorenzetti, El Nacimiento de la Virgen, 1335-42, temple sobre madera, 187 x $182 \mathrm{~cm}$. Museo dell’Opera del Duomo, Siena.

9 Entre esos textos apócrifos de la infancia de la Virgen sobresalen: Protoevangelio de Santiago. In: Santos Otero 2006, 130-170; Evangelio del Pseudo Mateo. In: Santos Otero 2006, 173-236; Libro de la Natividad de María. In: Santos Otero 2006, 238-252. 
un pináculo ojival independiente en su remate-, Lorenzetti unifica el relato en el contexto de un único edificio, visto en dos ambientes autónomos: en los paneles central y derecho representa la habitación matrimonial, donde la parturienta Ana y su neonata María son atendidas por parteras y sirvientas; en el panel izquierdo plasma una antesala, donde el anciano Joaquín, padre de la recién nacida, sentado junto a otro adulto más joven, recibe por boca de un niño la anhelada noticia del nacimiento de su hija.

En la alcoba conyugal, Ana, vestida de pies a cabeza y semiyacente en su limpio y ordenado lecho, recibe los cuidados de una joven con vestido rojo, que le procura alivio en los sofocos del alumbramiento refrescándola con un abanico trenzado en blanco y negro; a su vez, otras dos jóvenes sirvientas a la derecha le traen comida para su refrigerio, una jarra de agua o perfume y una toalla blanca para su higiene post-parto. En primer plano dos parteras bañan a la recién parida María, una de las cuales la sostiene en su brazo izquierdo mientras con la mano derecha palpa la tibieza del agua del barreño, que la segunda partera vierte con una jarra.

Entre esos elementos narrativos previsibles en semejante evento, interesa destacar aquí para nuestros fines la clara apariencia de templo o capilla - con rara mezcla de elementos góticos y clásicos- que Pietro Lorenzetti proporciona a la casa de Joaquín y Ana. Tal aspecto de templo se afirma por cuatro detalles significativos: ante todo, por la evidente forma de triple portada gótica (con el vano central más ancho que los dos laterales) que presentan los «marcos» que encuadran el tríptico, rematados en tres pináculos en arco ojival y decorados con «rosetones» trilobulados; además, por las bóvedas de crucería en cada uno de los tres módulos compositivos, todas ellas tachonadas de estrellas doradas, como sucede en muchas bóvedas de templos medievales; en tercer lugar, por la ventana bifora gótica que ilumina la antesala donde se sienta Joaquín; y en última instancia, por el alto y esbelto edificio, de gráciles ventanas góticas y elevado pórtico o claustro, perceptible a través de los vanos del fondo de la antesala de Joaquín, estableciendo una perfecta continuidad con las habitaciones íntimas de la casa de Ana visualizadas en los primeros planos.

Ahora bien, el hecho de configurar en forma de templo la escenografía de algunas imágenes de la Virgen -como este Nacimiento de María- no es una mera concesión decorativa o anecdótica del autor intelectual del cuadro, sino una firme decisión, plena de significados doctrinales, como mostraremos en las partes siguientes de este artículo.

Paolo di Giovanni Fei, en El Nacimiento de la Virgen, 1381, de la Pinacoteca Nazionale di Siena ${ }^{10}$ (Fig. 2), se inspira directamente en el recién analizado retablo que Lorenzetti plasmó cuatro décadas antes. Los dos únicos cambios relevantes que introduce Paolo di Giovanni Fei sobre el modelo de Lorenzetti consisten en invertir la posición de los personajes en las escenas centrales, y añadir -por exigencias del encargo- dos alas laterales (constituyendo así un políptico) para dar cabida a cuatro santos patronos: un apóstol o evangelista y santa Catalina de Alejandría en el panel izquierdo, y un segundo apóstol o evangelista y Santa Catalina de Siena en el derecho.

Pero, al margen de estas variantes de forma, el contenido narrativo y simbólico de este último políptico es esencialmente idéntico al del tríptico de Lorenzetti, aun

10 Paolo di Giovanni Fei, El Nacimiento de la Virgen, 1381, temple y oro sobre madera. Pinacoteca Nazionale di Siena. 


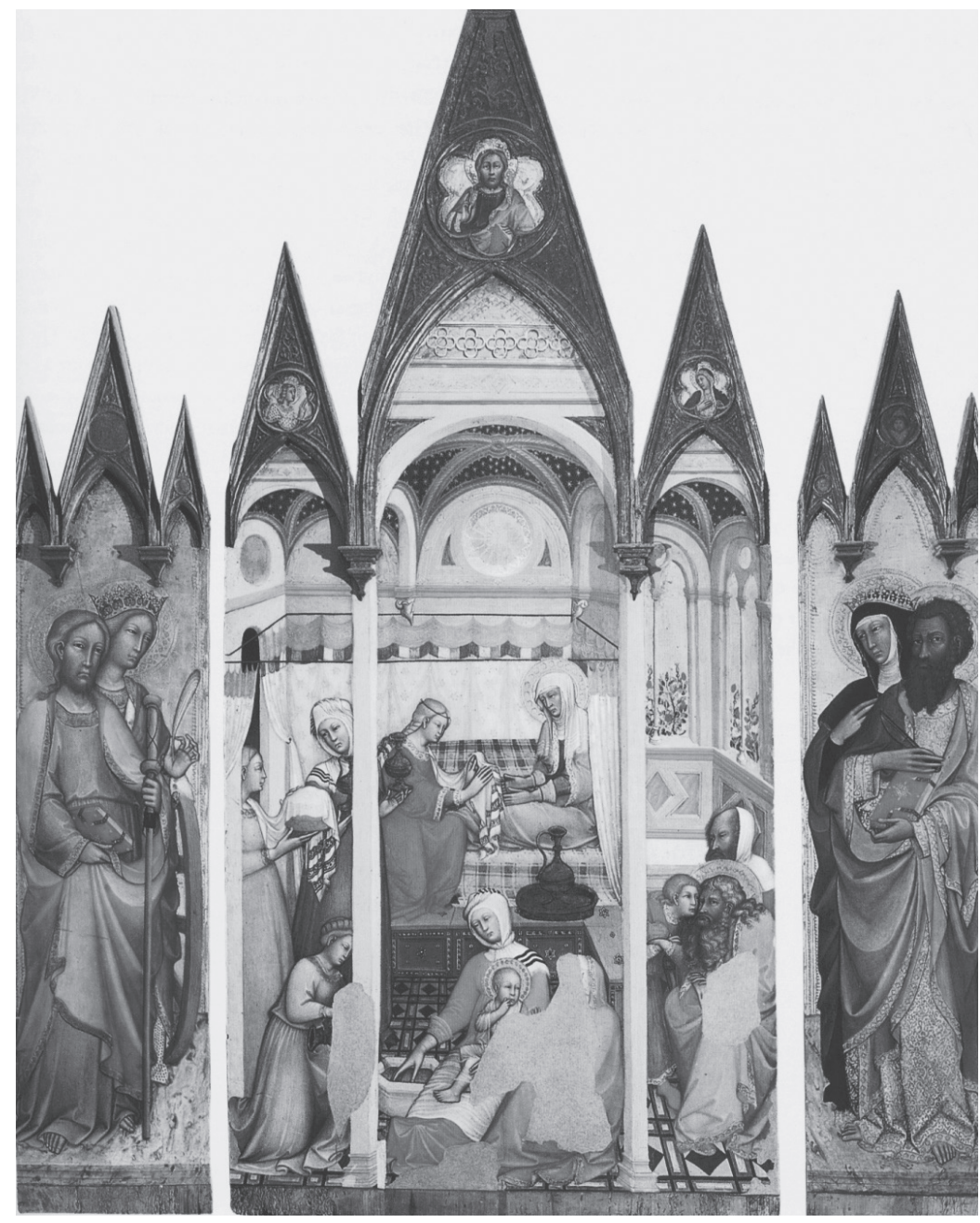

Fig. 2. Paolo di Giovanni Fei, El Nacimiento de la Virgen, 1381. Pinacoteca Nazionale di Siena. Imagen tomada de Wikimedia Commons https://commons.wikimedia.org/wiki/

File:Paolo_di_Giovanni_Fei._Birth_of the_Virgin._1381._Pinacoteca,_Siena..jM (Última consulta: 10/05/2016)

introduciendo algún personaje adicional. De hecho, además de las dos parteras que lavan a la recién nacida, una jovencita colabora en la tarea vertiendo el agua de la jarra en la pila. Por lo demás, Joaquín, sentado ahora en una antesala o solana abierta sobre un jardín, sigue estando en compañía de otro adulto, mientras un niño le cuchichea los detalles del nacimiento de su hija; y siguen siendo tres las sirvientas que ayudan a la aquí sedente Ana, dos de ellas trayendo la comida, el agua o el perfume y la toalla, mientras la tercera, vestida de rojo y sentada sobre el lecho, limpia a la parturienta de las manchas del parto con el agua de una jarra y el aguamanil cercanos, operación esta eufemísticamente sugerida por la discreta acción de secarle las manos con una toalla. 


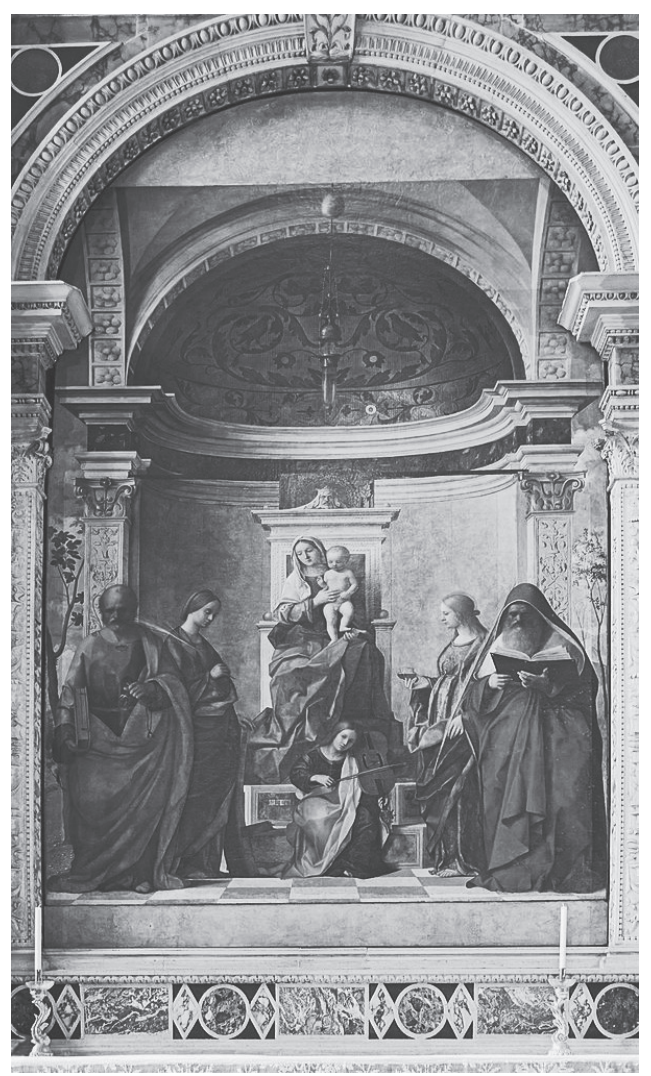

Fig. 3. Giovanni Bellini, Pala di San Zaccaria, 1505, iglesia de San Zacarías, Venecia. Imagen tomada de Wikimedia Commons https://commons.wikimedia.org/wiki/

Category:Pala_di_San_Zaccaria (Última consulta: 10/05/2016)

Exactamente como lo hizo Pietro Lorenzetti en el recién analizado tríptico de Siena, también Pietro di Govanni Fei da en este políptico a la casa de Joaquín y Ana la precisa apariencia de templo, como lo ponen de manifiesto las bóvedas de crucería tachonadas de estrellas que cubren las habitaciones, las ventanas góticas de la antesala o solana (similar a un claustro catedralicio o conventual), el marco de la escena central, que, a modo de triple portada gótica, se corona con gabletes ornados con bustos en rosetones polilobulados. Y, como Lorenzetti, también Paolo di Giovanni Fei parece tener presente las proyecciones teológicas de esta forma de templo en las escenas marianas.

Giovanni Bellini ${ }^{11}$, en la Pala di San Zaccaria, 1505, que aún permanece in situ en la iglesia de San Zacarías en Venecia ${ }^{12}$ (Fig. 3), es un ejemplo paradigmático del

11 Sobre Giovanni Bellini véanse, entre otros, Cammaerts 1912; Pallucchini 1961; Robertson 1968; Semenzato 1968; Pignatti 1969; Goffen 1986; Wilde 1988; Goffen 1989; Zuffi 1991; Tempestini 2000; Brown \& Ferino-Pagden 2006; Poldi \& Villa 2008; Olivari 2010.

12 Giovanni Bellini, Pala di San Zaccaria (Virgen con Niño en trono y Santos), 1505, óleo (originalmente sobre madera) transferido a tela, $500 \mathrm{~cm} \times 235 \mathrm{~cm}$. Iglesia de San Zacarías, Venecia. 
motivo iconográfico de la Sacra Conversazione. En este retablo -firmado y fechado IOANNES BELLINVS/MCCCCCV ${ }^{13}$ en un papel clavado sobre el escalón central del tronoel pintor reúne en torno a la Virgen entronizada con su Niño a los santos Pedro y Catalina de Alejandría, a nuestra izquierda, y Lucía y Jerónimo, a nuestra derecha, mientras un ángel, sentado en la primera grada del trono, tañe una lira da braccio ${ }^{14}$ en honor a la Reina del Cielo. Lo que incumbe destacar en esta obra es el edificio que cobija a los personajes. En efecto, aunque abierto hacia el paisaje por ambos lados, dicha construcción, de diseño renacentista, muestra una clara traza de templo o, para ser más exactos, de la cabecera de un templo, con su crucero de amplias arcadas (del que forma parte el arco/marco exterior que encuadra el conjunto) y con su ábside semicilíndrico cubierto por bóveda de horno enriquecida con mosaico de roleos vegetales y aves.

Esa sintética forma de templo pasa desapercibida a la mayoría de los comentaristas de este retablo ${ }^{15}$, y los pocos que la mencionan suelen hacerlo desde un enfoque meramente estilístico o compositivo ${ }^{16}$, o incluso desde la vertiente científico-técnica ${ }^{17}$. A no dudarlo, al situar en el centro mismo del ábside de ese metonímico templo a esta majestuosa Madonna con su monumental trono marmóreo - en el emplazamiento reservado al altar, y como si fuese el propio altar-, Giovanni Bellini parece insinuar la continuidad/identificación de la Virgen con el concepto mismo de «templo».

Jan van Eyck ${ }^{18}$, en La Virgen y el Niño con el canónigo van der Paele, 1436, del Groeningemuseum en Brujas ${ }^{19}$ (Fig. 4), encargada por el canónigo Joris van der Paele, representa a la entronizada María en el momento de entregar unas simbólicas flores a su desnudo Jesús, quien juguetea con un loro. Como interlocutores de la Reina de los Cielos y de su divino Hijo en esta Sacra Conversazione aparecen a nuestra izquierda San Donaciano, obispo de Reims, a quien está dedicada la catedral de Brujas, y, a nuestra derecha, San Jorge, santo patrón del canónigo van der Paele (Jorge es Joris en flamenco), a quien -devotamente arrodillado e interrumpiendo su meditación ante el libro de horas- protege y presenta ante la Virgen y el Niño.

Destaca aquí la fastuosa riqueza y el deslumbrante boato con que van Eyck plasma este retablo, tal como se aprecia en la Virgen, lujosamente cubierta con amplio manto de púrpura y abundantes joyas en la diadema y los bordes de la túnica y el manto. No menor exuberancia presenta su valioso trono, el cual -decorado en sus apoyabrazos con finos relieves (Adán y Eva en sus caras frontales) y esculturas (Caín matando a Abel, en el apoyabrazos derecho, y Sansón matando al león, en el izquierdo)- se halla protegido por espléndido dosel en brocado de oro con motivos vegetales, mientras los escalones de su peana y el piso lucen una primorosa alfombra oriental de motivos geométricos y fitomorfos. Esa inmensa opulencia se hace asimismo patente

\footnotetext{
Cf. Tempestini 2000, 148; Zucchetta 2008, 153.

Cf. Goffen 1989, 173.

Ninguna alusión a ese templo hacen Robertson 1968; Semenzato 1968, 72-73; Tempestini 2000, 148-149; Brown \& Ferino-Pagden 2006, 41; Olivari 2010, 62.

Cf. Goffen 1989, 174.

E. Zucchetta (2008, 153-167) estudia científicamente el historial y las restauraciones de este retablo.

18 Sobre Jan van Eyck véase, entre otros, Hymans [1907?]; Panofsky 1992 (1953); Friedländer 1967a; Faggin 1968; Brockwell 1973; Dhanens 1980; Lane 1984; Harbison 1991; Châtelet 1993; Seidel 1993; Yarza 1993; Stroo \& Syfer-d'Olne 1996; Hall 1997; Pächt 1999; Harbison 2000; De Vos 2002; Borchert 2002a; Borchert 2002b; Smith 2004; Ferrari 2005; Simpson 2007; Borchert 2008.

19 Jan van Eyck (c.1390-1441), La Virgen y el Niño con el canónigo van der Paele, 1436, óleo sobre madera, 122,1 $\mathrm{x} 157,8 \mathrm{~cm}$. Groeningemuseum, Brujas.
} 


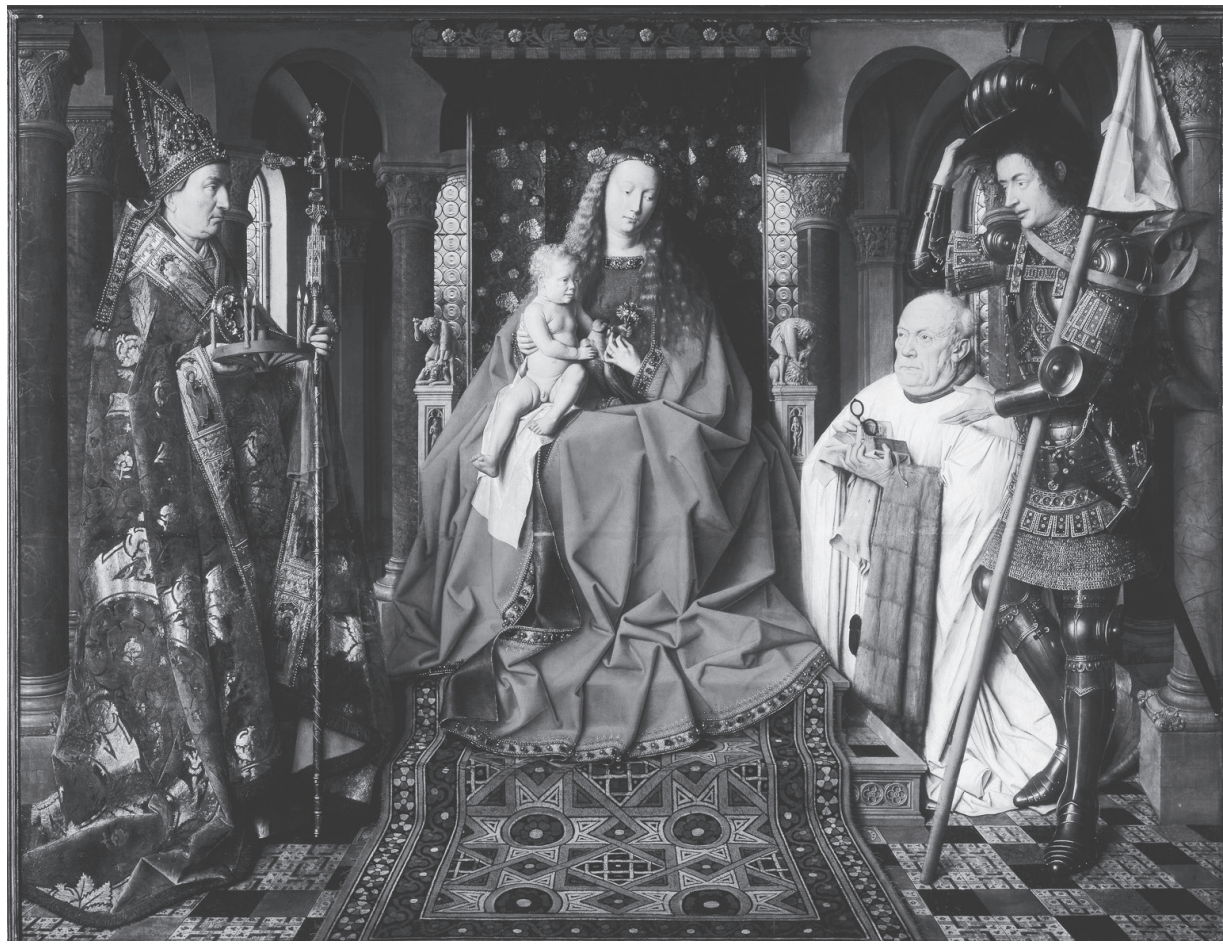

Fig. 4. Jan van Eyck, La Virgen y el Niño con el canónigo van der Paele, 1436, Groeningemuseum, Brujas. Imagen tomada de Wikimedia Commons https://commons. wikimedia.org/wiki/File:Jan_van_Eyck_069.jM (Última consulta: 10/05/2016)

en la riquísima indumentaria ceremonial de San Donaciano -capa pluvial de exquisito brocado y elaborados bordes figurativos en hilo de oro, lujosa tiara repleta de perlas y gemas, repujado báculo de oro y piedras preciosas-, así como en la refulgente armadura de San Jorge, plena de brillante damasquinado y engarzada al cuello con valiosa pedrería.

Importa subrayar aquí que van Eyck sitúa esta escena devocional en la cabecera de una iglesia románica ${ }^{20}$, con la enaltecida Virgen y su Niño ocupando en su trono el propio sitio del altar mayor. Revelan tal aspecto de templo las arquerías de medio punto de la luminosa girola, cuyas columnas y pilastras coronan capiteles historiados -en dos de los cuales se perciben al fondo, a la derecha del trono, los episodios de Abraham y Melquisedec, y el sacrificio de Isaac- o con entrelazados vegetales, de entre los que surgen a veces monstruos y animales fantásticos. Al plasmar como escenario de esta Sacra Conversazione una rotunda forma de iglesia -cuyo significado simbólico ignoran casi todos los comentaristas de este cuadro ${ }^{21}$, salvo Elisabeth

20 Al analizar este cuadro, Friedländer (1967a, 42-43) menciona esta forma de templo, refiriéndose al ábside románico con una galería que lo rodea por detrás, cuyas ventanas se hallan en parte cubiertas por las columnas, en el marco de una arquitectura curva. Pero nada dice sobre el significado de este templo.

21 Además del recién citado Friedländer, tampoco Panofsky (1992 (1953), 262), ni Harbison (1991, 48-63) ni Simpson $(2007,82-85)$ dicen nada sobre el significado simbólico de este templo. 
Dhanens ${ }^{22}$, van Eyck parece querer trasmitir aquí la idea de la relación de María con el «templo», en el sentido de metafórica identificación María $=$ templo ${ }^{23}$, como se mostrará luego.

Rogier van der Weyden ${ }^{24}$, en la Aparición de Jesús resucitado a María, panel derecho del Tríptico de Nuestra Señora (Retablo de Miraflores)25, c.1442-45, en la Gemäldegalerie de Berlín ${ }^{26}$ (Fig. 5), pone punto final a los tres episodios de la vida de la Virgen que constituyen esta tríada, cuyos dos primeros paneles representan la Natividad de Jesús (panel izquierdo) y el Descendimiento (panel central). Cada uno de esos tres paneles gemelos se enmarca con una portada «gótica» en arco de medio punto románico, cuya respectiva única arquivolta configura una serie de simbólicas esculturas con peana y dosel representando episodios del Antiguo y del Nuevo Testamento. En la portada de esta Aparición de Jesús resucitado a María, las escenas esculpidas en la arquivolta son, en la mitad izquierda, Pentecostés, la Ascensión y la Virgen dialogando con las tres Marías, mientras en la mitad derecha, y de abajo hacia arriba, aparecen el Anuncio de su muerte a María, la Virgen preparando su entierro (con la entrega de la palma al apóstol Juan) y la Asunción de María. Ocupan las jambas de esa tercera portada el evangelista San Marcos a la izquierda y San Pablo a la derecha ${ }^{27}$. Bajo la clave del arco, un ángel cubierto con túnica azul despliega una banderola, en la que -según transcribe Panofsky, desarrollando la escritura abreviada y modernizando la puntuación del texto pintado- aparecen inscritas estas frases bíblicas: «Mulier haec perseuerauit vincens omnia; ideo data est ei corona. Ex Apoc. $\mathrm{VI}^{\mathrm{o}}$ capitulo.» «Et data est ei [c'est-à-dire au cavalier au cheval blanc] corona, et exivit vincens ut vinceret. (Apocalypse, $\mathrm{VI}, 2)\rangle^{28}$.

Conviene destacar aquí que van der Weyden escenifica esta Aparición de Jesús resucitado a María dentro de un edificio que -detalle desapercibido por casi todos los comentaristas de este tríptico ${ }^{29}$ - presenta un incuestionable aspecto de capilla o pequeño templo gótico. Así lo dan a entender la planta de tres naves, las bóvedas de crucería y la espléndida portada que sirve de encuadre a la escena, con su arquivolta repleta de figuras escultóricas, e incluso, al fondo de la escena, la doble puerta con

22 En su amplio análisis de este retablo, Dhanens (1980, 212-231) ofrece esta interesante interpretación sobre el simbolismo del templo pintado en él: «In fact, a Christian symbolism is superimposed on the more personal relations represented here. Mary sits in the place normally reserved for the altar, and in a way represents it: she holds her son, the Saviour made man, on her knees just as the altar displays the Body and Blood of Christ during the Mass. The church interior of course symbolises the ecclesiastical community, the mystic body of Christ.» (Ibid., 220). Por desgracia, Dhanens no justifica sus afirmaciones con argumentos extraídos de la multisecular tradición patrística y teológica.

23 Panofsky (1992 (1953), 332-333) nada dice sobre el templo ni sobre su significado en este retablo.

24 Sobre R. van der Weyden véanse Panofsky 1992 (1953); Friedländer 1967b; Davis 1973; Lane 1984; Delenda 1995; Stroo \& Syfer-d'Olne 1996; Châtelet 1999a; Châtelet 1999b; De Vos 1999; Dhanens y Dijkstra 1999; Pächt 1999; De Vos 2002; Nieto Alcaide 2003; Smith 2004; Rothstein 2005; Nash 2008; Kemperdick \& Sander 2009; Campbell \& Van der Stock 2009; Jones 2011; Fransen 2013;Campbell 2015.

25 Este retablo fue donado por el rey Juan II en 1445 a la Cartuja de Miraflores (Burgos).

26 Rogier van der Weyden, Aparición de Jesús resucitado a María, panel derecho del Tríptico de Nuestra Señora (Retablo de Miraflores), c.1442-45, óleo sobre madera, $71 \times 43 \mathrm{~cm}$ cada panel (213 x $43 \mathrm{~cm}$, todo el tríptico). Gemäldegalerie, Berlín.

27 Los personajes de las jambas de esta tercera portada se completan con los apóstoles de las dos primeras portadas: en las jambas de la primera están Pedro y Lucas; en las de la segunda, Juan y Mateo.

28 Panofsky 1992 (1953), 733, nota 50. «Esta mujer perseveró venciendo todo, por eso se le dio la corona.» «Y se le dio [al jinete del caballo blanco] una corona, y salió venciendo para vencer.»

29 Al comentar esta obra Friedländer (1967b) no hace ninguna referencia al templo. Tampoco Panofsky, en su largo análisis sobre el tríptico (1992 (1953), 459-468), dice nada sobre este templo, salvo una mera alusión a que las tres escenas están «inscrites dans des portails richement sculptés» (Ibid., 459). 


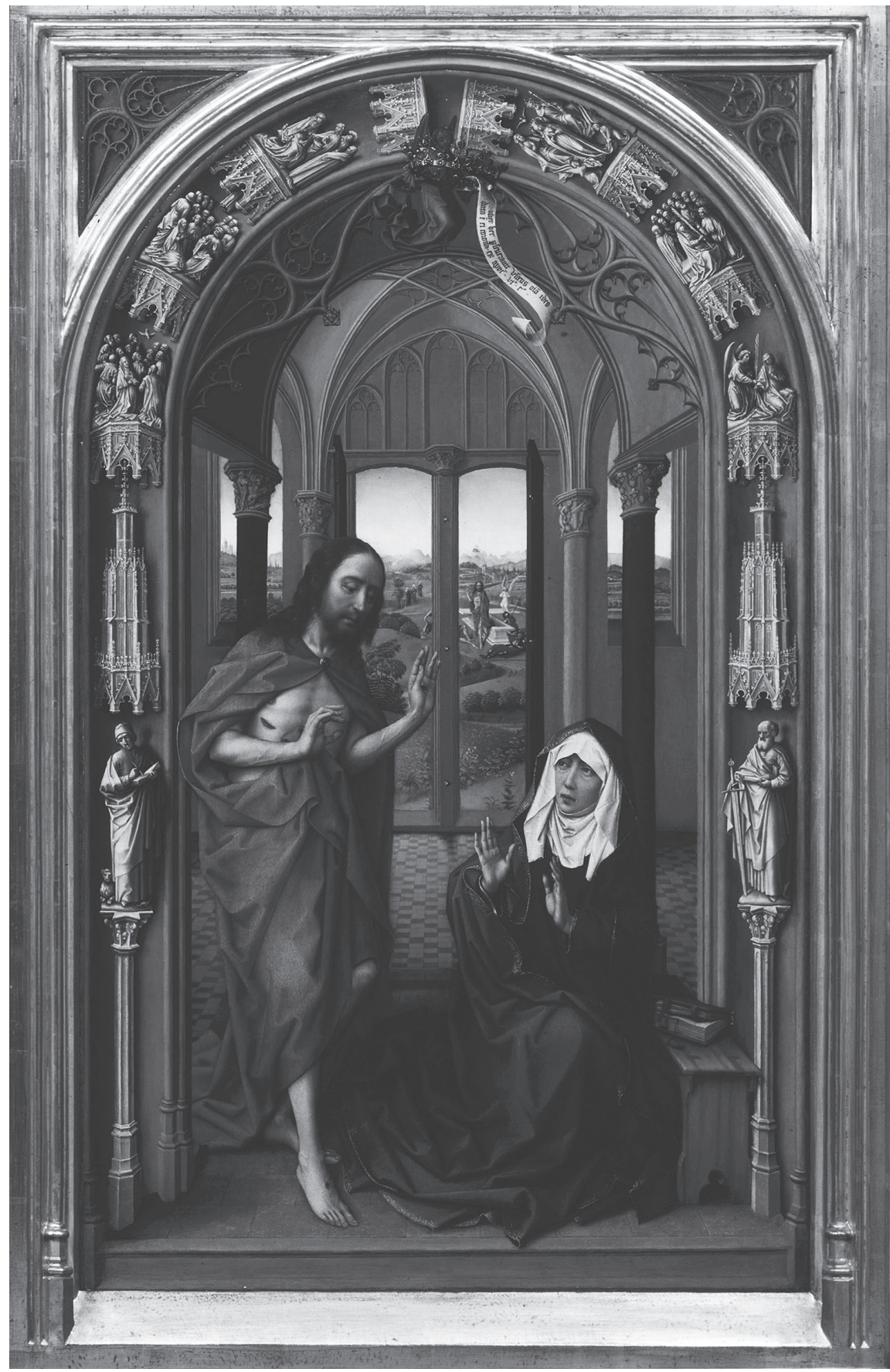

Fig. 5. Rogier van der Weyden, Aparición de Jesús resucitado a María, panel derecho del Tríptico de Nuestra Señora (Retablo de Miraflores), c. 1442-45. Gemäldegalerie, Berlín. Imagen tomada de Wikimedia Commons https://commons.wikimedia.org/wiki/File:Rogier van_der_Weyden_-_The_Altar_of_Our_Lady_(Miraflores_Altar)_-_Google_Art_Project_ (right_panel_without_frame).jM (Última consulta: 10/05/2016) 


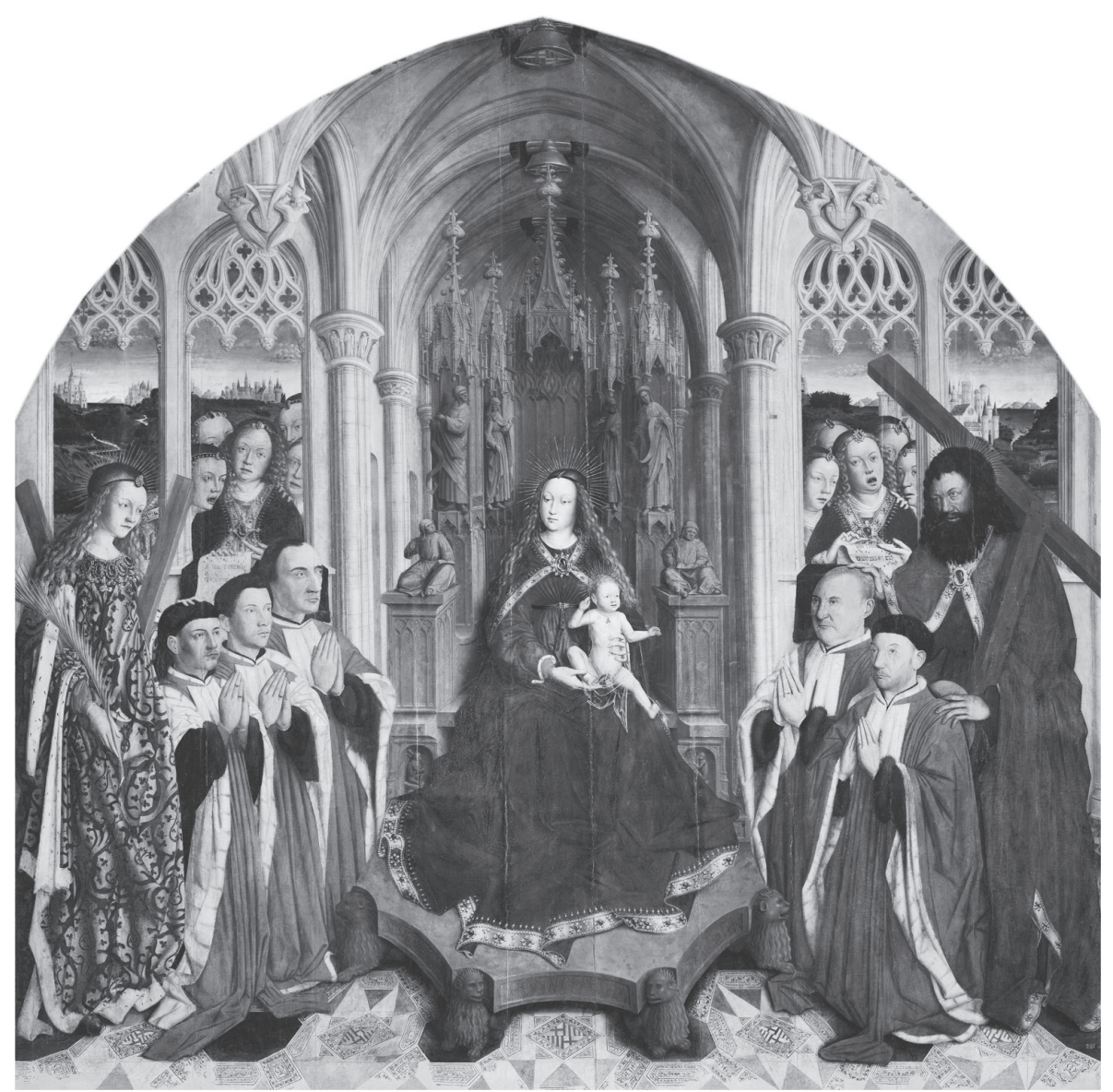

Fig. 6. Lluís Dalmau, Mare de Deu dels Consellers, 1445. Museu Nacional d'Art de Catalunya, Barcelona. Imagen tomada de Wikimedia Commons https://commons.wikimedia. org/wiki/File:Dalmau_Mare_de_Deu_dels_Consellers.jM (Última consulta: 10/05/2016)

parteluz y tímpano ojival, que, generosamente abierta hacia el paisaje exterior, deja ver el doble episodio de la Resurrección de Cristo ante los soldados que custodian el sepulcro (en la parte derecha de la puerta) y (en su parte izquierda) la venida de las tres Marías para depositar aromas en la tumba, antes de conocer por el ángel (quien pisa la tapa del sarcófago, en señal de triunfo sobre la muerte) la resurrección del Redentor. Así, al plasmar esta aparición del resucitado a María en un edificio con evidente aspecto de capilla o pequeña iglesia, van der Weyden parece hacer suya la tradición doctrinal que define a María como templum Dei, como se verá en los dos próximos apartados.

Lluís Dalmau, en su retablo de la Mare de Deu dels Consellers, 1445, en el Museu Nacional d'Art de Catalunya, Barcelona ${ }^{30}$ (Fig. 6), recalifica el motivo de

30 Lluís Dalmau, Mare de Deu dels Consellers, 1445, óleo sobre madera, 311,5×311 cm. Museu Nacional d'Art de Catalunya, Barcelona. 
la Sacra Conversazione, al disponer a la Virgen (vestida con manto azul y orlas de oro y joyas) con el Niño en su regazo en medio de los cinco consejeros del gobierno municipal de Barcelona. De hecho, los únicos elementos que en forma genuina vinculan este retablo con la Sacra Conversazione son Santa Eulalia y San Andrés -cada uno con su atributo de martirio, presentando ante la Virgen a los cinco munícipes-y los dos coros de ángeles cantores que se siluetean sobre el paisaje a ambos costados.

Para realzar el lujo y la riqueza que deben corresponder tanto a los Soberanos celestiales (María y Jesús) como a los propios munícipes barceloneses, Dalmau instala la escena en un esplendente edificio gótico flamígero, abierto hacia el paisaje a través de ventanales de tracería calada, mientras coloca a la Reina del Cielo sobre un exuberante trono gótico, coronado por refinado dosel a múltiples pináculos, embellecido con estatuas y realzado sobre cuatro leones, en los bordes de cuya peana el pintor firma y fecha la obra: SUB ANNO MCCCCXLV PER LUDOVICUM DALMAU FUI DEPICTUM.

Conviene enfatizar aquí que el edificio gótico en que Dalmau escenifica esta solicitud de intercesión de los cinco consejeros de Barcelona exhibe un obvio aspecto de iglesia ${ }^{31}$. Así lo testifican la nave cubierta con bóvedas de crucería apeadas sobre pilares fasciculados con capiteles fitomorfos o de figuras humanas, cuyo ábside se halla colmado al completo -justo en el emplazamiento del altar mayor- por el monumental trono en que se sienta la Mare de Deu. Es precisamente esa apariencia de iglesia la que utiliza Dalmau para sugerir la ya referida identificación simbólica María=templo.

Piero della Francesca ${ }^{32}$, en la Pala di Brera o Pala Montefeltro (conocida como La Madonna dell'Uovo), c.1472, en la Pinacoteca di Brera de Milán ${ }^{33}$ (Fig. 7), representa una Sacra Conversazione con seis santos, cuatro ángeles y el donante Federico da Montefeltro, duque de Urbino. Según Alessandro Angelini y Antonio Paolucci, esta obra habría sido pintada originalmente como retablo para la iglesia franciscana de San Donato degli Osservanti en Urbino, donde este condottiero estuvo sepultado algún tiempo ${ }^{34}$; otros expertos, como Lionello Venturi y Ronald Lightbown, sostienen que el destino primigenio del cuadro fue la nueva iglesia franciscana de San Bernardino en Urbino, donde se construyó el mausoleo de Federico da Montefeltro $^{35}$. Obviando esos debates historicistas, nos motiva comprender los significados inherentes a esta obra.

Escoltada por cuatro ángeles, la Virgen, sedente sobre sencillo trono, cuyo escabel está cubierto por una rica alfombra oriental, adora con las manos juntas al divino Niño adormecido en su regazo. El pintor coloca a la derecha de la enaltecida Soberana celestial y su hijo a los santos Juan Bautista, Bernardino de Siena y Jerónimo, mientras a su izquierda (a nuestra derecha) sitúa a los santos Francisco de Asís, Pedro Mártir y Juan Evangelista. Por delante de estos últimos, recogido en devota oración ante la Madonna y el Niño, el duque Federico da Montefeltro aparece humil-

\footnotetext{
31 En su comentario sobre esta obra de Dalmau, Yarza Luaces $(2002,132)$ nada dice sobre el templo.

32 Sobre Piero della Francesca, véanse Longhi 1989 (1927); Clark 1951; Busignani1967; Hendy 1968; Clark 1969; de Vecchi 1970; Venturi 1990; Lavin 1990; Centauro 1990; Bairati 1991; Angelini 1991; Paolucci 1991; Battisti 1992; Damisch 1997; Lightbown 1992; Lavin 2002; Bertelli \& Paolucci 2007; Daffra 2007.

33 Piero della Francesca, Pala di Brera o Pala Montefeltro (La Madonna dell'Uovo), c.1472, temple y óleo sobre madera, $248 \times 170 \mathrm{~cm}$. Pinacoteca di Brera, Milán.

34 Cf. Angelini 1991, 70; y Paolucci 1991, 142.

35 Cf. Venturi 1990, 108; y Lightbown 1992, 246.
} 


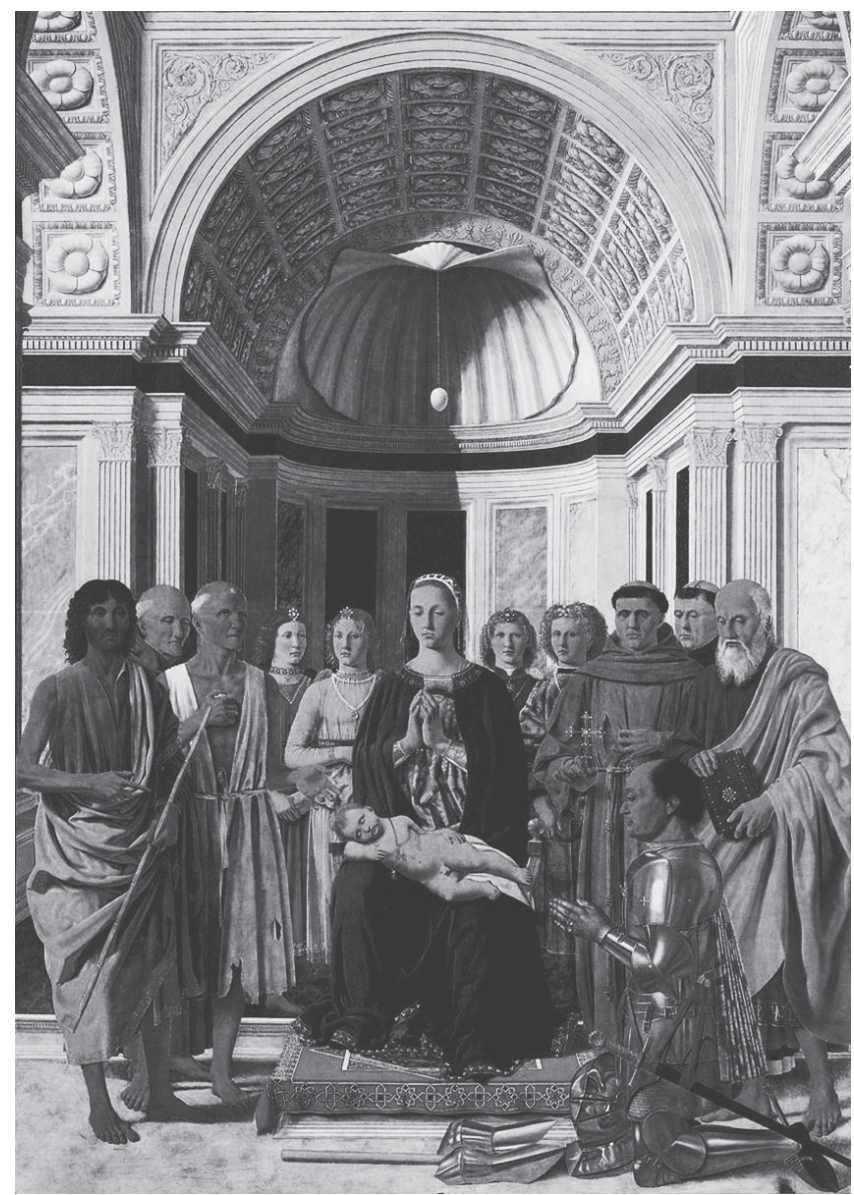

Fig. 7. Piero della Francesca, Pala di Brera o Pala Montefeltro (La Madonna dell'Uovo), c. 1472. Pinacoteca di Brera, Milán. Imagen tomada de Wikimedia Commons https:// commons.wikimedia.org/wiki/File:Piero_della_Francesca_-_Madonna_and_Child_with_

Saints_(Montefeltro_Altarpiece)_-_WGA17615.jM (Última consulta: 10/05/2016)

demente arrodillado, aunque soberbiamente revestido con su armadura de condottiero y teniendo junto a sí el bastón de mando, el yelmo y las manoplas, atributos significativos de su extraordinario poder militar, político y social ${ }^{36}$.

Cabe poner de relieve que Piero della Francesca ambienta esta Sacra Conversazione en el crucero de una lujosa iglesia renacentista de mármoles policromos: su cabecera con nave cubierta por bóveda de casetones de rosetas culmina en un ábside

36 Al analizar la Pala di Brera, Lavin $(1991,88)$ aporta estos datos: «His [de Piero della Francesca] purpose [...] was to provide personal significance for the figure of the donor, once more pressed close to the picture plane, Federico da Montefeltro is depicted in a full armor, with helmet, gauntlets and baton of command. He is the first such armored donor in seventy-five years of Italian painting. In August of 1474 Federico was created Knight of St Peter's, Gonfaloniere of the Church of Rome, and general of the Vatican armies. Piero shows him, not as a traditional supplicant asking for protection or giving thanks, but pledging himself as a Soldier of Christ, an eternal sentinel guarding the Holy Roman Church.» 
semicilíndrico rematado por una bóveda de horno en forma de concha de peregrino, de cuya cúspide pende de un hilo de oro un simbólico huevo de avestruz (que da nombre popular al cuadro: Madonna dell'Uovo). A ambos lados se despliegan otras dos naves (que, al parecer, conforman el transepto), enmarcadas por sendos arcos de casetones a rosetas, similares a los de la nave de la cabecera.

Muchos comentaristas de este Pala di Brera eluden por completo el templo en ella pintado, como sucede con Alberto Busignani ${ }^{37}$, Roberto Longhi ${ }^{38}$, Lionello Venturi ${ }^{39}$ y Antonio Paolucci ${ }^{40}$, o lo tratan en un sentido meramente compositivo, como lo hacen Erwin Panofsky ${ }^{41}$, Kenneth Clark ${ }^{42}$, Alessandro Angelini ${ }^{43}$, o Emmanuela Daffra $^{44}$. Por su parte, y a sus expensas, Ronald Lightbown, tras asumir la tesis de algunos expertos, que ven en este cuadro un planteamiento matemático ${ }^{45}$, asegura que lo representado aquí por Piero no es un templo, sino la «Corte Celestial» ${ }^{46}$.

Esa categórica forma de iglesia, que con clara intención Piero proporciona a la estructura escenográfica de este retablo franciscano, permite suponer que el artista - con la probable ayuda de un mentor intelectual de la orden de los Hermanos Menores- se ajusta a la tesis doctrinal que identifica simbólicamente a la Virgen María con el templo de Dios. Y no basta con afirmar que el templo pintado aquí por Piero simboliza la identificación de María con la Iglesia institucional, como lo hacen, tan taxativa como gratuitamente, Marilyn A. Lavin ${ }^{47}$ y Antonio Paolucci ${ }^{48}$, sin aportar ningún argumento teológico o doctrinal. Precisamente argumentos exegéticos formulados por Padres de la Iglesia y teólogos medievales nos proporcionarán en las dos siguientes partes de este ensayo los fundamentos dogmáticos para dar al templo pintado en los cuadros que comentamos una interpretación doctrinal bien diferente a la que los referidos comentaristas aventuran sin ninguna justificación documental.

37 A. Busignani $(1967,77)$ no dice nada sobre el templo.

38 Longhi 1989, 162-166.

39 En su análisis de la obra, Venturi (1990, 108-110) no menciona siquiera el templo.

40 Paolucci 1991, 144-147.

41 Panofsky (1992 (1953), 23-25) contrapone la forma de «iglesia» pintada por Piero della Francesca a la representada antes por Jan van Eyck en La Virgen del canónigo van der Paele.

42 Clark $(1969,231)$ considera este templo como un mero elemento matemático-geométrico.

43 Angelini 1991, 70.

44 En su comentario sobre este cuadro, Daffra $(2007,57-58)$ no se interesa por el templo ahí plasmado.

45 Cf. Lightbown 1992, 245.

46 En forma gratuita Lightbown $(1992,251)$ no duda en asegurar: «The setting [de la Pala di Brera] was to be the Court of Heaven, or Curia Coeli, as was obligatory, since it was here that his soul [la de Federico da Montefeltro] and its protectors would make their plea to Christ for mercy. By a curious aberration, this setting, as figured by Piero, has been identified since 1898 as a church. Churches are not built into Heaven, where the Church itself is triumphant; they belong to this world, where the Church is militant. In the Courts of Heaven even its central sacrifice of the Mass no longer has a place. The identification arose because Piero, quite exceptionally, has shown the Court of Heaven as apparently cruciform in shape, preceded, that is, by a hall leading from this picture plane into the crossing. [...] This want of clear spatial delimitation in heavenly architecture is usual in religious paintings of all kinds; the purpose of such settings was to suggest rather than confine heavenly magnificence.»

47 Sin aportar argumentos doctrinales, Lavin $(1990,88)$ proclama sobre esta Pala di Brera: «By this backdrop arrangement [la organización de la perspectiva de un ábside de iglesia visto a distancia: NdA], Piero gives the image of the Madonna and Child the symbolism of 'Mary-Ecclesia', that is, Mary as a symbol of the Church as a corporate institution, traditionally illustrated by a change in scale.»

48 Con similar gratuidad, Paolucci $(1991,142)$ asegura sobre la Pala di Brera: «Au point de vue iconographique, cette peinture peut se lire à plusieurs niveaux. Il y a le thème strictement religieux, qui s'inspire de la tradition flamande: la Madonna à l'intérieur d'une église s'identifie à l'Église universelle.» 


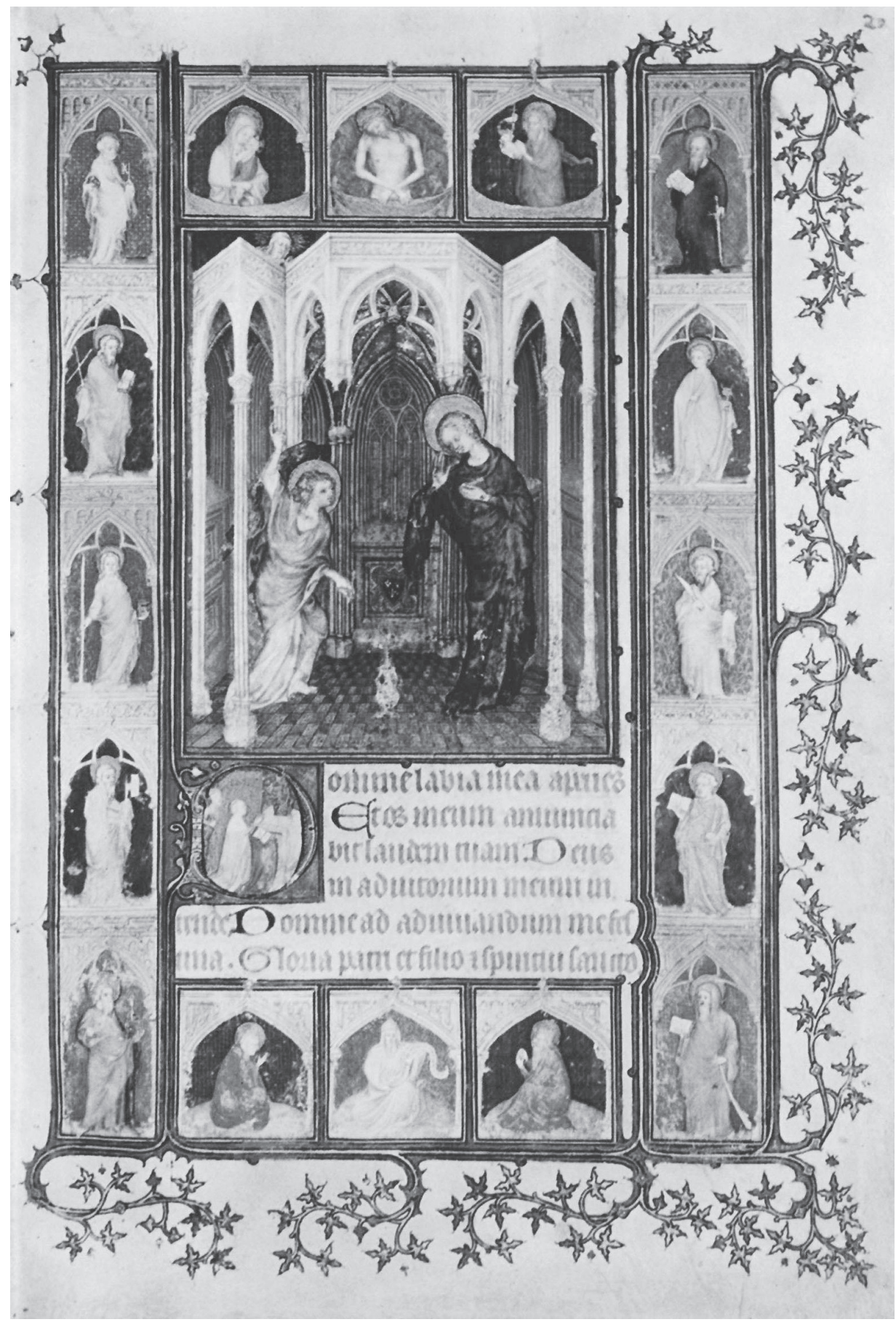

Fig. 8. Jacquemart de Hesdin, La Anunciación, miniatura de Les Petites Heures du Duc de Berry, c. 1380-1385. Bibliothèque Nationale de France, Paris (Ms. Lat.18014) Imagen tomada de Wikimedia Commons https://commons.wikimedia.org/wiki/File:Jacquemart_de Hesdin_-_The_Annunciation_-_WGA11924.jpg?uselang=fr (Última consulta: 10/05/2016) 


\subsection{Representaciones integrales del templo en imágenes marianas de los siglos XIV-XV}

Esta segunda variante iconográfica, que plasma el templo en su práctica totalidad en representaciones de la Virgen María durante las dos citadas centurias, se ejemplifica bien en las cinco obras de Jacquemart de Hesdin, el Maestro de Boucicaut, Jan van Eyck y Rogier van der Weyden que se examinan de inmediato.

Jacquemart de Hesdin, en la miniatura de La Anunciación de Les Petites Heures du Duc de Berry, c.1380-138549, hoy en la Bibliothèque Nationale de France, París (Ms. Lat.18014) $)^{50}$ (Fig. 8), ofrece un premonitorio prototipo de esta modalidad tipológica que ambienta algún episodio mariano en la totalidad esencial de un templo. Enmarcándola con una rica orla de dieciséis personajes insertos en hornacinas ojivales -entre ellos, en la banda superior, el Varón de Dolores entre la Virgen y San Juan Bautista-, el miniaturista ubica la Anunciación de la escena central en el interior de una resplandeciente iglesia gótica, convirtiendo así la humilde casa de María en un magnífico templo. Señalando con su índice derecho hacia quien le envía, Dios Padre -cuya cabeza emerge en el borde superior izquierdo de la escena central-, el arcángel Gabriel inicia el gesto de arrodillarse ante la Virgen. De pie, vestida de azul y retrayendo un tanto su cuerpo con tímido pudor, esta interrumpe su meditación ante el libro de horas que sostiene en su mano izquierda, mientras, inclinando su cabeza y abriendo su mano derecha, hace un gesto de sumiso beneplácito de ancilla Domini ante el designio divino.

Bajo la miniatura principal se leen en tinta roja los versículos iniciales del Officium Beatae Mariae Ad Matutinum, que sirven de introducción a las oraciones propias de esa parte del Libro de las Pequeñas Horas del Duque de Berry:
Domine labia mea aperies.
Et os meum annunciabit laudem tuam.
Deus in adiutorium meum intende.
Domine ad adiuvandum me festina.
Gloria patri et filio et spiritui sancto ${ }^{51}$.

A no dudarlo, Jacquemart de Hesdin, tal vez instruido por algún clérigo como programador iconográfico de su miniatura, plantea aquí la tesis del templo como figura metafórica de la Virgen María.

Como lo hizo casi treinta años antes Jacquemart de Hesdin en la recién estudiada miniatura del Libro de Horas del Duque de Berry, también el Maestro de Boucicaut, en La Anunciación del f53v del Livre d'Heures du Maréchal Boucicaut, c.1410-15, hoy en el Musée Jacquemart-André de París ${ }^{52}$ (Fig. 9), ilustra esta segunda variante iconográfica que investigamos. El Maestro de Boucicaut, en efecto, convierte el

49 Esta datación temprana de las Petites Heures du Duc de Berry es defendida por Panofsky (1992 (1953), 87), frente a la fecha convencional de hacia 1400, que suele asignarse a dicho códice.

50 Jacquemart de Hesdin, La Anunciación, miniatura de Les Petites Heures du Duc de Berry, c.1380-1385, miniatura sobre pergamino, 21,5x14,5 cm. Bibliothèque Nationale de France (Ms. Lat.18014).

51 « OOh Señor, Tú abrirás mis labios / y mi boca anunciará tu alabanza! / OOh Dios, ven en mi auxilio! / ¡Oh Señor, apresúrate a ayudarme! / Gloria al Padre y al Hijo y al Espíritu Santo.» (Traducción del autor).

52 Maestro de Boucicaut, La Anunciación, miniatura del Livre d'Heures du Maréchal Boucicaut, f. 53v, c.1410-15, miniatura sobre pergamino. Musée Jacquemart-André, París. 


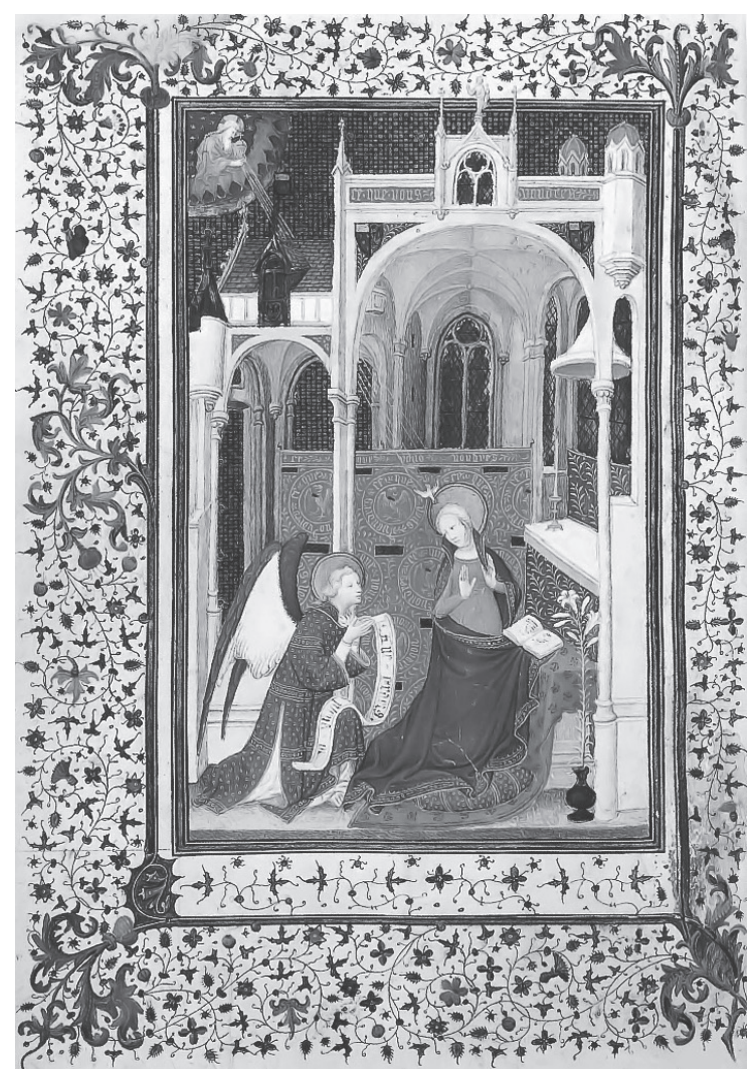

Fig. 9. Maestro de Boucicaut, La Anunciación, minatura del Livre d'Heures du Maréchal Boucicaut, f53v, c. 1410-15, Musée Jacquemart-André, París Imagen tomada de Wikipedia https://ca.wikipedia.org/wiki/Llibre_d\%27hores_de_Boucicaut\#/media/File:BoucicautMeister.jM (Última consulta: 10/05/2016)

humilde hogar de María en un esplendoroso templo ${ }^{53}$ de tres naves, en el que arcos de medio punto y sencillos soportes románicos se combinan de modo extraño con bóvedas de crucería y ventanas geminadas con tracería, gabletes y pináculos de estilo gótico.

El miniaturista organiza este episodio en forma bastante convencional. En el ángulo superior izquierdo, flotando entre querubines sobre el piñón de la fachada Norte del templo, aparece Dios Padre emitiendo el fecundador haz de rayos - con la paloma del Espíritu Santo en su estela- hacia la cabeza/oído de la Virgen, ilustrando así la tesis de la conceptio per aurem ${ }^{54}$. Dentro de la amplia iglesia, cuya

53 Al analizar esta miniatura, Panofsky (1992 (1953), 117) apunta, entre otras cosas, que «La scène de 1' “Annonciation', en souvenir évident de Jacquemart de Hesdin, se déroule dans une sorte de chapelle, vue à la fois du dedans et du dehors». Pero, al margen de algunos apuntes estilístico-formales que esboza al respecto, Panofsky omite cualquier interpretación simbólica del templo pintado en esta Anunciación.

54 Sobre la tesis de la conceptio per aurem, véanse Jones 1923 (1914); Remigereau 1947; Steinberg 1987; Urbaniak-Walczak 1991; y, en especial, Salvador González 2014 y Salvador González 2015. 
cabecera y nave izquierda están bloqueadas visualmente por un colgante de seda roja con emblemas heráldicos, el artista sitúa a los dos interlocutores de este episodio. Doblando con respeto su rodilla derecha ante su Señora, el ángel inicia el diálogo con ella mediante la salutación AVE MARIA GRATIA PLENA, que luce inscrita en la banderola que despliega frente a sí. De rodillas ante su libro de oraciones en un reclinatorio cubierto con paño rojo floreado en el crucero del templo ${ }^{55}$, la Virgen gira su cuerpo y su rostro hacia Gabriel, mientras abre sus manos en gesto de Virgo orans para evidenciar su irrestricta sumisión ante la voluntad del Omnipotente. La presencia de la paloma del divino Espíritu sobre la cabeza de María (Spiritus Sanctus superveniet in te et virtus Altissimi obumbrabit tibi ${ }^{56}$ ) y el tallo de lirios surgiendo del florero en primer plano simbolizan la virginal maternidad divina de María, que se hace efectiva en el instante de su asentimiento ante el designio divino. En tal sentido, al transformar en templo la casa de la doncella, el Maestro de Boucicaut identifica simbólicamente a María como templum $D e i^{57}$.

En el Tríptico de Dresde, firmado y fechado en 1437, de la Gemäldegalerie Alte Meister de Dresde ${ }^{58}$ (Fig. 10), Jan van Eyck ofrece una contundente prueba de la vigencia de esta segunda tipología iconográfica, que integra la totalidad de un templo en alguna imagen de María. De hecho, el artista unifica compositiva y narrativamente los tres paneles de este tríptico ${ }^{59}$ desplegando en ellos un templo de planta basilical y estilo híbrido, que combina arcos de medio punto y columnas simples de capiteles historiados en estilo románico, junto con expresivas esculturas que, encuadrando la nave central sobre las columnas, se hallan protegidas por doseletes con pencas y florones de estilo gótico. En el panel central van Eyck sitúa a la Virgen, quien, ceñida su cabeza con una diadema de piedras preciosas, y ataviada con amplio manto rojo orlado con oro y gemas, sostiene a su Niño en brazos. Les sirve de asiento un trono tallado con figuras doradas, protegido por un baldaquino en paño de brocado con ornamentos vegetales y animales, mientras una alfombra oriental de motivos abstracto-geométricos cubre su peana. Por relación con la escala del edificio, el enorme trono y la monumental Virgen y su Niño -que despliega hacia el donante una filacteria con la didascalia DISCITE A ME, QUIA MITIS SUM ET HUMILIS CORDE ${ }^{60}$ - plenan casi por completo la larga nave central de ese vistoso templo. En la nave izquierda de esa basílica (en el panel izquierdo del tríptico) el arcángel San Miguel, cubierto con lujosa armadura de fino damasquinado, presenta ante la entronizada Madre de Dios al donante del cuadro (probablemente un clérigo), arrodillado en devota oración. El panel derecho representa a Santa Catalina de Alejandría, ceñida con lujosa corona y

55 De que la Virgen ocupa en esta miniatura el centro del transepto del templo se colige por el hecho de que se halla en el cruce del eje longitudinal que desemboca en el abside y el eje transversal de ambos transeptos: el de la derecha (el Sur) está «velado» por una especie de tela verde con motivos vegetales, en lo que parece una alusión al hortus conclusus; el de la izquierda (Norte) tiene su puerta abierta hacia el exterior, y se cubre con la visible estructura con techumbre a dos aguas, cuya fachada se corona con el piñón decorado con florones, bajo la figura de Dios Padre. Para no obliterar la figura de Gabriel, el miniaturista ha tenido que hacer una «trampa» a la lógica constructiva, disponiendo por detrás del arcángel la «crujía» noroeste en que se apea el crucero, la cual es el pendant simétrico de la columna del primer plano a la derecha, junto al florero de lirios.

56 Lc.1: 35. In: Biblia Sacra juxta Vulgatam Clementinam 2005, 1.011.

57 Panofsky (1992 (1953), 116-117) omite el significado doctrinal del templo pintado en la miniatura.

58 Jan van Eyck, Tríptico de Dresde (Virgen con Niño con San Miguel, Santa Catalina y donante), 1437, óleo sobre madera, 33 x 27,5 cm. Gemäldegalerie Alte Meister, Dresde.

59 Los dos paneles exteriores de este tríptico - visibles cuando este se halla cerrado- representan por separado y en grisalla al arcángel Gabriel y a la Virgen María en la escena de la Anunciación.

60 Mat. 11:29. In: Biblia Sacra juxta Vulgatam Clementinam, $2006^{12}, 973$. 


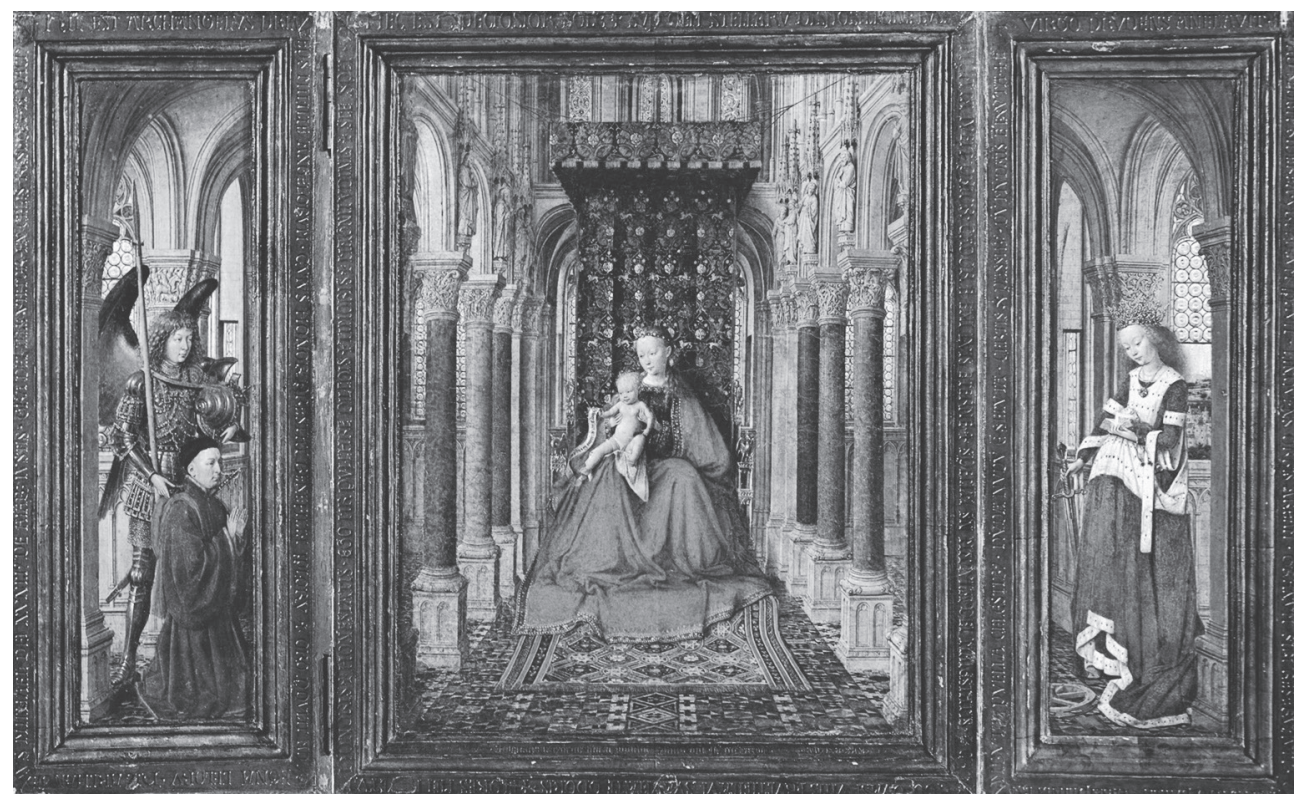

Fig. 10. Jan van Eyck, Tríptico de Dresde (Virgen con Niño con San Miguel, Santa Catalina y donante), 1437. Gemäldegalerie Alte Meister, Dresde. Imagen tomada de Wikimedia Commons https:/commons.wikimedia.org/wiki/File:Dresden-triptych-4394. jM (Última consulta: 10/05/2016)

cubierta con ricas vestiduras, quien, absorta en la meditación ante el libro de horas abierto en su mano izquierda, sostiene con su derecha la espada, mientras a sus pies yace la rueda dentada, atributos ambos de su martirio.

Al escenificar este Tríptico de Dresde en el contexto de una iglesia -cuyo significado doctrinal pasa desapercibido a casi todos los comentaristas, como Friedländer ${ }^{61}$, Panofsky ${ }^{62}$, Dhanens ${ }^{63}$ y Simpson ${ }^{64}$, o bien es interpretado en un sentido distinto al nuestro, como lo hace Harbison ${ }^{65}$, , van Eyck, con la probable asesoría de algún eclesiástico, tuvo sin duda en cuenta las enseñanzas patrísticas y teológicas que identifican a María con el templo de Dios.

Jan van Eyck, en la pequeña tabla La Virgen en la iglesia, c.1438-40, de la Gemäldegalerie de Berlin ${ }^{66}$ (Fig. 11), lleva a su máxima expresión la idea de identificar a María como metafórico templum Dei. Por tal motivo, representa a la Virgen y al Niño, ambos a escala agigantada respecto al contexto escenográfico, como únicos

61 En su análisis de esta obra Friedländer (1967a, 62) no menciona el templo pintado.

62 En su doble comentario sobre esta obra, Panofsky (1992 (1953), 262 y 347-349) se limita a reseñar algunos detalles románicos y góticos del templo, sin interesarse por su significado doctrinal.

63 En su largo análisis de este tríptico, Dhanens (1980, 242-251) se entretiene en los elementos compositivos y formales del templo pintado (Ibid., 246 y 248), pero sin aludir a su significado simbólico.

64 Al comentar esta obra, Simpson $(2007,94-95)$ omite referirse al significado del templo, del que solo proporciona algunos detalles estilístico-formales

65 Harbison (1995, 129-132, 134-135 y 151-157) da sobre el significado del templo una interpretación personal, que comentaremos más adelante.

${ }^{66}$ Jan van Eyck, La Virgen en la iglesia, c.1438-40, óleo sobre tabla, 31 x 14 cm.Gemäldegalerie, Berlin. 


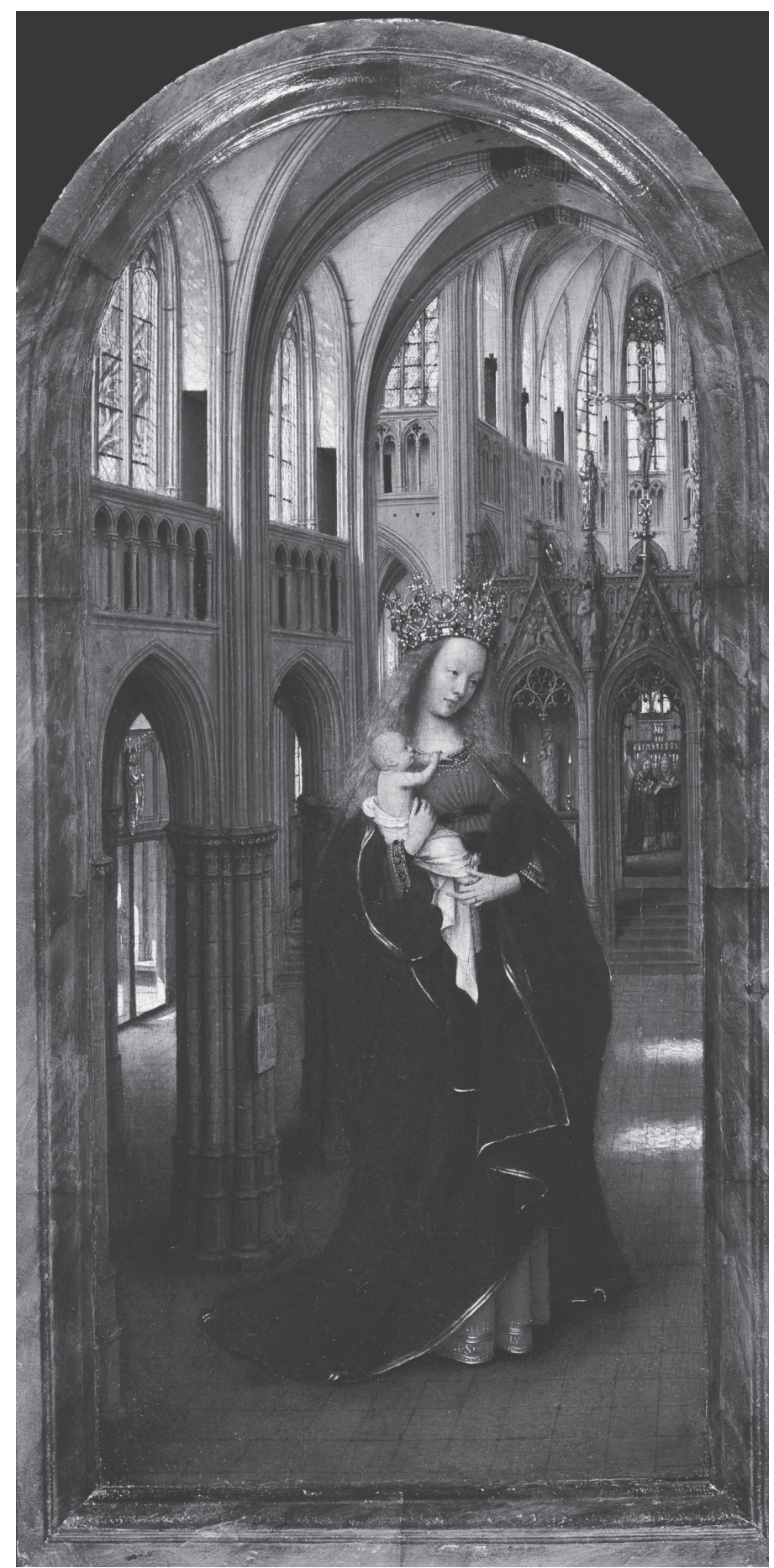

Fig. 11. Jan van Eyck, La Virgen en la iglesia, c. 1438-40, Gemäldegalerie, Berlin. Imagen tomada de Wikimedia Commons https://commons.wikimedia.org/wiki/File:Jan_van_Eyck_The_Madonna_in_the_Church___Google_Art_Project.jM (Última consulta: $\overline{10} / 0 \overline{5} / 2016$ ) 
habitantes -salvo la pareja de ángeles cantores que se entrevén a través del baldaquino o templete gótico en el centro del transepto- de esa imponente catedral gótica, la cual llenan casi por completo con sus descomunales figuras. Por si fuera poco, al mismo tiempo que pone en luz la imponente efigie de María como mayestática Reina de los Cielos - ceñida con corona de oro y piedras preciosas, y con gemas deslumbrantes en las orlas de su vestido rojo-, van Eyck multiplica una y otra vez, en melódicos ecos, la presencia de la Virgen mediante repetidas imágenes escultóricas de ella en diversas partes del templo por detrás de su gigantesco cuerpo viviente. Justo a sus espaldas, en efecto, se aprecia entre dos cirios encendidos una estatua de María con su Niño en brazos, presidiendo el nicho visible del baldaquino; en el piñón del gablete que corona ese nicho se distingue en relieve la escena de la Anunciación, mientras en el gablete de la puerta del templete se representa la Coronación de la Virgen; y, como coronamiento de los pináculos centrales del baldaquino, se erige la Crucifixión de Cristo entre la Virgen (a su derecha) y San Juan Evangelista (a su izquierda, medio cortado por el marco). En el mismo sentido de presencia mariana (vicaria, esta vez) debe entenderse el detalle de los dos ángeles revestidos con capas pluviales, quienes, visibles a través del vano del templete, interpretan con su libro abierto cánticos celestiales en honor a la Reina de los Cielos.

Algunos comentaristas de este cuadro, desinteresándose del posible significado doctrinal de la iglesia gótica en que se halla la Virgen, se entretienen solo en describir sus aspectos meramente estilísticos o formales, como lo hacen Friedländer ${ }^{67}$, van Puyvelde ${ }^{68}$, Simpson $^{69}$ y Harbison ${ }^{70}$. Otros autores, sin aportar ningún argumento de fuentes primarias teológicas, ven en este cuadro una representación clara de María como Iglesia institucional, tal como lo afirman a sus expensas Panofsky ${ }^{71}$,

67 Al analizar esta obra Friedländer (1967a, 52) dice solo que para esta catedral Jan van Eyck parece haber usado el mismo modelo que utilizó en La misa de difuntos, en el Libro de Horas de Turín-Milán.

68 Al comentar esta obra, van Puyvelde $(1968,51)$ solo dice: «Une réelle disproportion se marque entre cette grande figure et l'architecture du monument, envisagé en somme comme un simple décor autour du personnage. L'église est de construction bourguignonne».

69 Cf. Simpson $(2007,110-111)$.

70 Al analizar este panel, Harbison (1991, 137-138) nada dice sobre el templo. Sin embargo, en el capítulo 16 de su libro («Architectural style and Sculptural Symbolism», 151-157), al abordar el significado de las iglesias pintadas por van Eyck, Harbison defiende que la arquitectura propia de este artista, altamente decorativa, alude al mismo tiempo a la Iglesia institucional y al establishment del rico laicado, como perfecto complemento de las funciones en competencia de los paneles en su conjunto. (Ibid., 132). Harbison ofrece así un nuevo caso de interpretaciones gratuitas, sin pruebas documentales.

71 Al analizar este panel de van Eyck, Panofsky (1992 (1953), 268-276), enfrentando a quienes critican la desproporción entre la figura de la Virgen y la catedral en que se aloja, afirma a sus expensas y sin argumentos doctrinales: «En réalité, ce tableau représente moins la Vierge dans une église que la Vierge image de l'Église, c'est-à-dire, moins un être humain à l'échelle d'un édifice réel qu'une personnification de cette même puissance ou entité spirituelle, que traduit, en termes d'architecture, le sanctuaire qui l'enchasse. Cette interprétation picturale, malgré son apparence de naturalisme, est conforme à une tradition séculaire, dans le fonds comme dans la forme." (Ibid., 269). Y poco después insiste: «Afin d'exprimer dans le langage de l'art cette identité mystérieuse et multiple de la Vierge, considérée comme Mère, Mère et Fille, Fille et Fiancée, Reine des cieux et Église du Christ sur la terre, il fallait inventer une représentation où l'on pût voir à la fois la "Vierge dans une église" et la "Vierge, symbole de l'Église".» (Ibid.). Aparte de lo sugerente que pueda parecer este planteamiento, importa sobremanera saber en qué fuentes patrísticas o teológicas se funda Panofsky para aventurar semejante interpretación. Al respecto, el autor se conforma con brindar este lábil argumento: «Depuis que les Pères de l'Église avaient donné du Cantique des cantiques une explication allégorique, le Fiancé était identifié au Christ, et la Fiancée, à l'Église, laquelle, à son tour, trouvait en Marie une personnification mystique. "Tout ce qui est dit de l'Église", écrit Honorius d'Autun, dont le commentaire du Cantique des cantiques fit autorité absolue, "on peut le comprendre comme concernant la Vierge elle-même, Fiancée et mère du Fiancé".» (Ibid., 269). Al margen de lo poco convincente que resulta afirmar que «les Pères de l'Église»-sin mencionar a ninguno en particular- 
Dhanens ${ }^{72}$ y Borchert ${ }^{73}$. Ahora bien, frente a tales afirmaciones -tan parcialmente ciertas como del todo injustificadas-, creemos necesario complementar y, sobre todo, justificar esas interpretaciones, demostrando que la monumentalización de la Virgen ocupando casi por entero una catedral completa significa identificar a María como simbólico templum Dei, en los sentidos dogmáticos que mostraremos en los dos epígrafes siguientes.

Rogier van der Weyden, en el Tríptico de los Siete Sacramentos, c.1445-5074 -encargado en 1441 por el obispo de Tournai, Jean Chevrot ${ }^{75}$, como retablo para su capilla privada, y hoy en el Museo de Bellas Artes de Amberes $^{76}$ (Fig. 12)-, eleva también a su máxima potencia la identificación simbólica de María con el templum Dei. De hecho, van der Weyden unifica de igual modo en este retablo-como lo hizo van Eyck en el ya comentado Tríptico de Dresde-los tres paneles del tríptico mediante la única estructura de una colosal catedral gótica ${ }^{77}$, cuya nave central vista hacia la cabecera ocupa el panel principal del retablo, mientras sus alas izquierda y derecha dan cabida a las correspondientes naves laterales del templo ${ }^{78}$.

Unificada así la escenografía arquitectónica, van der Weyden distribuye en cada panel las distintas escenas sacramentales que constituyen el nudo narrativo del retablo. En el panel izquierdo, correspondiente a la nave lateral izquierda, ubica las

identificaron a la Iglesia institucional con la Esposa del Cantar de los Cantares (afirmación válida para algunos Padres de la Iglesia, pero no para todos), en las dos siguientes partes de este artículo mostraremos con abundantes citas que muchos Padres, Doctores de la Iglesia y teólogos medievales identifican simbólicamente a la Virgen María -e incluso a su vientre- con el templum Dei, en virtud de su exclusivo privilegio de ser la virginal Madre de Dios Hijo encarnado.

72 En su análisis de esta obra, Dhanens (1980, 316-328) asume la recién expuesta interpretación de Panofsky. Valen también para Dhanens las mismas críticas hechas a Panofsky en la nota precedente.

73 Al analizar esta obra de van Eyck ya en un primer trabajo sobre el artista y su entorno, Borchert (2002b, 18) afirma que el cuadro La Virgen en la iglesia «reproduit d'autre part la structure spatiale complexe d'une cathédrale gothique baignée de lumière. Il visualise ainsi l'assimilation, fréquente en théologie, de la mère de Dieu à l'Ecclesia tout en peignant l'une des représentations d'intérieur parmi les plus ambitieuses et les plus modernes de toute la peinture flamande.» En su posterior monografía de Van Eyck (2008), Borchert insiste en esta interpretación, al asegurar: «Con el pequeño altar [el Tríptico de Dresde], La Virgen en la iglesia tiene en comun la superficie final, un interés similar por la luz como medio dramatúrgico y, por último, el interés por la arquitectura. Mientras que, en los otros casos, Van Eyck se orientó por la arquitectura sacra románica, aquí el pintor introdujo a la Virgen en el contexto de una arquitectura más moderna, de las catedrales góticas, para ilustrar la metáfora de la Virgen como "Ecclesia". [...] Por su gigantesca escala -la cabeza de la Virgen alcanza la zona del triforio-, aquí se identifica a María con la iglesia: Van Eyck no solo presenta a "la Virgen en la iglesia", sino a la "Virgen como Iglesia".» (Borchert 2008, 63). Y, en el comentario a la foto en la nota al margen de esa misma página, Borchert insiste: «En relación con el tamaño de la iglesia, María tiene unas dimensiones gigantescas: Van Eyck no presenta a "la Virgen en la iglesia", sino que escenifica de modo plástico el simil de "Maria como Iglesia".» (Ibid., nota al margen). Solo nos cabe reiterar que esa identificación que -repitiendo la tesis de Panofsky- Borchert hace aquí de «María como Iglesia» es tan parcialmente cierta como totalmente injustificada, al no presentar argumentos teológicos que la prueben.

74 Panofsky (1992 (1953), 502-503), aun aceptando la autoría de van der Weyden sobre la idea del cuadro, otorga su ejecución material (que él considera «sin inspiración») a uno de sus asistentes.

75 Cf. Panofsky 1992 (1953), 502.

76 Rogier van der Weyden, Tríptico de los Siete Sacramentos, c.1445-50, óleo sobre madera, $200 \times 223 \mathrm{~cm}$, todo el tríptico (200 cm x $97 \mathrm{~cm}$, el panel central). Museo de Bellas Artes, Amberes.

77 Friedländer (1967b, plate 16) analiza este tríptico, sin mencionar el significado del templo.

78 En su amplio análisis de este Tríptico de los 7 Sacramentos, De Vos (1999, 217-225) no indica nada sobre el simbolismo del templo plasmado en él, y se contenta con destacar algunos elementos estilísticos y ciertos discutibles «datos» históricos, al afirmar: «L'intérieur lui-même est celui d'une église brabançonne de style gothique tardif, qui rappelle la cathédrale Saint-Michel (autrefois église Sainte-Gudule) à Bruxelles, bien que celui-ci ne fût pas encore achevé lors de la création du tableau. Sauerländer $(1997,167)$ a fait remarquer que les chapelles latérales possèdent une voûte en berceau, assez inhabituelle, comme celle de la cathédrale de Tournai.» (De Vos 1999, 220). 


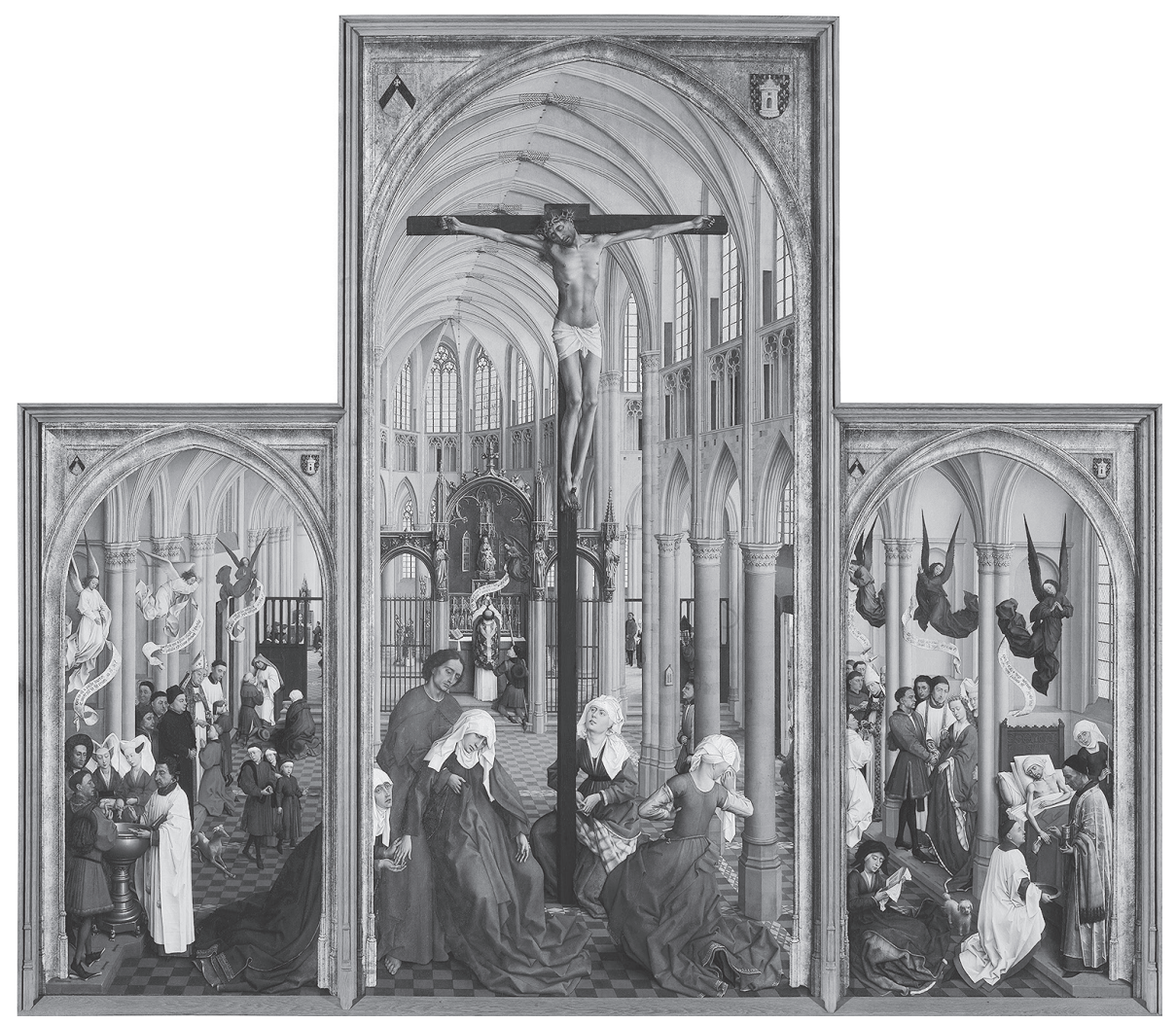

Fig. 12. Rogier van der Weyden, Tríptico de los Siete Sacramentos, c. 1445-50. Museo de Bellas Artes, Amberes. Imagen tomada de Wikimedia Commons https://commons. wikimedia.org/wiki/File:Seven_Sacraments_Rogier.jM (Última consulta: 10/05/2016)

escenas del Bautismo, la Confirmación y la Confesión. En el panel derecho, que identifica a la nave derecha de la iglesia, aparecen figuradas las escenas del Orden sacerdotal, el Matrimonio y la Extremaunción. El panel del centro, correspondiente a la ancha y alta nave central del templo, está dominado por el agigantado grupo de la Crucifixión ${ }^{79}$, con Cristo ya muerto sobre una elevada cruz, en torno a quien se hallan la desvanecida Virgen María, sostenida en volandas por San Juan Evangelista, mientras las tres Marías muestran su tristeza arrodilladas en el suelo. En el plano intermedio de este panel central, se observa la escena del sacramento de la Eucaristía, protagonizada por un sacerdote que en el momento de la consagración eleva la Sagrada Forma en el precioso altar sito en el centro del crucero, cuya escultura central figura a la Virgen entronizada con el Niño, en su distinguida condición de Trono de Dios y Sedes Sapientiae.

Pese a que, a primera vista, este tríptico de Amberes pudiera parecer heterogéneo y desordenado, la compacta unidad compositiva y jerárquica creada por la

79 La escala de las seis figuras del grupo de la Crucifixión, incluyendo la Virgen, es mucho mayor que las de las otras personas incluidas en las escenas de los sacramentos en los espacios del templo. 
estructura arquitectónica de esta imponente catedral ${ }^{80}$, como también el agigantamiento de la escala y la puesta en primer plano de los personajes de la Crucifixión, en especial, la Virgen, abonan la idea de que van der Weyden está sugiriendo en este excepcional retablo la tesis de identificar a María como metafórico templo de Dios, con todas las implicaciones dogmáticas que se precisarán en las dos partes siguientes del artículo.

\section{Exégesis patrísticas y teológicas sobre la significación de María como templum Dei}

La notable reiteración con la que artistas originarios de Flandes, Italia, Francia y España -y podríamos haber considerado también pintores de otros países europeosincluyen un templo o iglesia en las escenas marianas más diversas, desde el Nacimiento de la Virgen o la Anunciación hasta la Sacra Conversazione, no puede ser una mera coincidencia, ni es posible considerar dicho templo pintado como un anodino detalle escenográfico o decorativo, carente de significado. Tratándose de representaciones de temas marianos muy relevantes, es lícito conjeturar que las fuentes bíblicas, patrísticas y teológicas -en las que se inspiran los autores intelectuales de las obras de arte sacro- proporcionan las claves para interpretar a cabalidad semejante elemento arquitectónico.

De hecho, la indagación sistemática en los escritos de los Padres, Doctores de la Iglesia y teólogos medievales nos ha permitido cosechar un amplio florilegio de textos exegéticos sobre la figura retórica del templum Dei como elocuente metáfora de María, en cuyo virginal seno tomó cuerpo el Hijo de Dios hecho hombre, y, de rebote, también como complementaria metáfora del propio cuerpo humano de Dios Hijo al encarnarse en las entrañas de la Virgen. En ese orden de ideas, la pesquisa revela una concordante y sólida tradición exegética entre los escritores de la Iglesia, tanto en el Oriente greco-oriental como en el Occidente latino, desde el siglo IV hasta fines de la Edad Media.

Así, ya hacia la segunda mitad del siglo IV, San Zenón de Verona apunta en un escrito sobre la Natividad de Jesús que, al cumplirse el tiempo, el Hijo de Dios, ocultando su majestad divina y abandonando su sede celestial, se asentó en el templo de la predestinada Virgen María (es decir, en sus entrañas) para ser engendrado como hombre, cuya naturaleza no poseía ${ }^{81}$. Unos treinta años después San Ambrosio de Milán asegura en su carta 30 que, al momento de buscar un templo en el que habitase el Señor Jesús para redimir a la Humanidad, no buscó piedras ni maderas trabajadas con manos humanas, sino que escogió el vientre de la Virgen María para convertirlo en el salón regio y el templo en que habitase el Rey de los cielos ${ }^{82}$. Y en su carta

80 En su amplio análisis de este tríptico, Panofsky (1992 (1953), 502-507) describe las formas de esta catedral pintada, pero omite interpretar su significación doctrinal.

81 «Etenim Deus Dei Filius, tempore constituto, dissimulata interim majestate, ab aetherea sede profectus, in praedestinatae virginis templum sibimet castra metatur, quibus latenter infunditur in hominem gigniturus, ibidemque salvo quod erat meditatur esse, quod non erat.» (Zen.Ver., Tract. S. Zenonis Lib. II. Tract. VIII. De Nativ. Dom. II. ML 11, 413-415).

82 «Neque enim terrenorum parietum constructiones, et silvestrium ligna culminum desiderabat, quae cum fuissent, manus dirueret hostilis; sed illud templum quaerebat, quod in hominum conderetur mentibus, quibus dicendum foret: Vos estis templum Dei (I Cor. 3, 10), in quo habitaret Dominus Jesus, et unde ad redemptionem 
63 San Ambrosio se pregunta sobre cómo ponderar cuán grande fue la gracia de la virginidad de María, que mereció ser elegida por Cristo para ser el templo corpóreo de Dios, en el que habitó la plenitud de la divinidad, conservándose ella al mismo tiempo virgen al engendrar al Salvador del mundo y al dar a luz a la Vida de todos los hombres ${ }^{83}$.

Una generación más tarde San Máximo de Turín asegura que al útero de María, en vez de útero, es preferible llamarlo templo, pues este es el templo en que habita todo lo santo existente en el cielo (Dios Hijo), templo que debe ser considerado más valioso incluso que el propio cielo, casi como si el misterio divino se instalase en el tabernáculo más secreto ${ }^{84}$. De modo que al útero de María hay que considerarlo claramente superior a los cielos, pues devolvió al cielo al Hijo de Dios en una forma mucho más gloriosa que la que tenía al descender del cielo a la tierra; pues regresó al cielo para reinar, después de descender humillado entre los hombres, y subió glorificado al Padre. Por tanto, es mucho mejor el templo del cuerpo (María) que el templo del cielo ${ }^{85}$.

Como se ve, San Zenón, San Ambrosio y San Máximo plantean la interpretación -aceptada y ampliamente difundida por muchos autores posteriores- de que el templum Dei se identifica con María como totalidad hipostática, y con su vientre como órgano en el que se verifica la concepción/encarnación del Hijo de Dios hecho hombre.

Casi por las mismas fechas San Jerónimo afirma tajantemente que el cuerpo recibido por Cristo de la incorrupta Virgen María no se le convirtió en corrupción, sino en templo sagrado ${ }^{86}$. Con tal enunciado San Jerónimo inaugura una segunda interpretación -no opuesta, sino complementaria de la anterior y, por ello, asumida con entusiasmo por otros muchos escritores eclesiásticos-, según la cual el templum Dei que la divinidad se fabricó para sí es el propio cuerpo humano que Dios Hijo tomó de María al encarnarse como hombre en su vientre.

Más o menos un cuarto de siglo después, San Cirilo de Alejandría unifica y armoniza esas dos interpretaciones dadas hasta entonces por separado, al insistir una y otra vez en la figura del «templo» como símbolo que identifica tanto a María (su vientre virginal) como al cuerpo o naturaleza humana que el divino Hijo asumió en el seno de aquella al encarnarse. Así, en un comentario a Malaquías, el pensador

universorum procederet, ut in utero Virginis sacra reperiretur aula, in qua Rex habitaret coelestium, et corpus humanum Dei templum fieret; quod etiam, cum solutum esset, in triduo resuscitaretur.» (Ambr.Med., Ep. $X X X$, 3. ML 16, 1062).

83 «Quid autem loquar quanta sit virginitatis gratia, quae meruit a Christo elegi, ut esset etiam corporale Dei templum, in qua corporaliter, ut legimus (Coloss, II,9) habitavit plenitudo divinitatis? Virgo genuit mundi salutem, virgo peperit vitam universorum. Sola ergo non debet esse virginitas, quae omnibus in Christo profuit? Virgo portavit, quem mundus iste capere ac sustinere non potest. Qui cum ex Mariae nasceretur utero, genitalis tamen septum pudoris, et intemerata virginitatis conservavit signacula. Itaque in Virgine Christus reperit, quod suum esse vellet, quod sibi omnium Dominus assumeret. Per virum autem et mulierem caro ejecta de paradiso, per virginem juncta est Deo.» (Ambr.Med., Ep. LXIII, 33. ML 16, 1249-1250).

84 «Mariae ergo uterum non uterum dixerim fuisse, sed templum; templum plane est, in quo habitat sanctum quidquid in coelo est: nisi quod super coelos aestimandum est, ubi quasi in secretiore tabernaculo mysterium a divinitate disponitur, quemadmodum a pluribus ascendatur ad coelum.» (Maxim. Taur., Serm.2, 3. ML 57, 236).

85 «Super coelos plane aestimandus est uterus Mariae, quia Filium Dei gloriosiorem remisit ad coelum, quam de coelo descenderat. Inde enim ut pateretur, hinc reversus est, ut regnaret: inde humiliatus descendit in hominem, hinc gloricatus ad Patrem ascendit. Melius plane templum corporis est, quam coeli.» (Ibid.).

86 «Nos autem scimus de incorrupta virgine corpus assumptum, non corruptionem Christi fuisse, sed templum.» (Hier.Strid., In Ion. 2. ML 25, 1136). 
alejandrino sostiene que, cuando se dice que el Hijo de Dios vendrá a su templo, eso puede significar dos cosas: o bien que el Verbo de Dios se hizo carne y habitó en el castísimo cuerpo de la santa Virgen María como en un templo, o bien que habitó en un ser humano perfecto, cuyo cuerpo fue inmediatamente complementado con el alma y la providencia divina ${ }^{87}$. En un comentario al Evangelio de Juan el mismo autor apunta que,

después de que «la Sabiduría se edificó para sí una casa», como indica la Escritura, y un tabernáculo más verdadero, es decir, el templo construido de la Virgen María, el Verbo divino que está en el seno de su Dios Padre descendió dentro de ella por una incomprensible y divina razón, y se hizo hombre ${ }^{88}$.

Y en un tratado sobre la encarnación de Cristo, San Cirilo asegura que, en virtud de la gracia divina, el Verbo de Dios Unigénito nació de la Virgen María, tras asumir de esta únicamente la materia para fabricar el templo (el cuerpo) y unirse a él; y ni al ser concebido violó la virginidad de su madre, ni la rompió al nacer, sino que la conservó incólume e intacta, logrando así un prodigio inenarrable ${ }^{89}$. Por último, en un sermón para la Pascua San Cirilo reitera su tesis de que Cristo tomó de María el cuerpo humano como el propio templo en cuyo interior pudiese Él habitar. A juicio del Padre alejandrino, el cuerpo es el templo en el que el Hijo de Dios habitó, conjuntándose con el velo de la carne, pero integrándose ambos -el ser divino y la naturaleza humana- en un solo ser de manera inefable; y, como el Verbo divino habitó en su propio templo (su cuerpo o naturaleza humana), al asumir de una mujer (María) el cuerpo dotado de alma racional, reformó hacia la propia gloria aquel cuerpo verdadero que había asumido ${ }^{90}$.

Hacia esos mismos años San Proclo de Constantinopla argumenta que, si el Verbo de Dios no hubiese habitado en el vientre de María, la carne (es decir, la naturaleza humana) no se habría sentado en el trono santo de Cristo; y, si para Dios hubiese sido ignominioso penetrar en el útero que él mismo había formado, habría también dado a todos los hombres semejante deshonra al ser engendrados ${ }^{91}$. En su tercera homilía sobre la encarnación de Cristo, el prelado constantinopolitano, tras preguntarse cuándo la carne o naturaleza humana se unió substancialmente a Dios, y cuándo la santa Virgen preparó su útero para ello, alega que el Verbo penetró en el seno de

87 «Venturum porro ad templum suum dicit, aut quia Verbum caro factum est, et tanquam in templo quod e castissimo sanctae Virginis corpore susceperat, habitavit: aut in homine perfecto, qui ex corpore, inquam, et anima immediate et divina providentia coagmentatus esse creditus est.» (Cyr.Al., Malach. 2, 32. M 72, 332).

88 «Postquam "Sapientia aedificavit sibi domum," ut scriptum est, ac verius tabernaculum, id est templum illud ex Virgine sibi exstruxit, descendit in ipsam incomprehensibili ac divina ratione qui est in sinu Dei ac Patris sui Deus Verbum, et homo factus est». (Cyr.Al., Com.Jo.. Lib. IV, IV, 3. M 73, 615).

89 «Huius rei gratia unigenitum Dei Verbum ex sola Virgine materiam fabricae sumens, atque ita illaboratum formans templum, sibique uniens, prodit ex Virgine, haud equidem in conceptu solvens virgineam zonam, neque hanc nativitate dirumpens, sed incolumen intactamque conservans, atque ita magnum hoc et inenarrabile patrans prodigium.» (Cyr.Al., Inc.23. M 75, 1459-1462).

90 «Haec vero dicent, templum quoque in quo inhabitavit, sejungentes illud velamento carnis, sed unum ex utroque ineffabili modo coagmentatum. Habitavit siquidem divinum Verbum in proprio templo, corpore nimirum assumpto ex muliere anima rationali praedito, verum in propriam gloriam quod assumpserat reformavit.» (Cyr. Al., Hom.Pasc.VIII, 6. M 77, 574).

91 «Nisi enim Verbum uterum inhabitasset, neque caro consedisset in throno sancto. Si Deo ignominiae esset in uterum illabi quem ipse formarat, esset quoque probro hominibus ministrare." (Procl.CP, Or.I.Laud.M. M 65, 683). 
María por su oído y el Espíritu Santo construyó en ella un templo vivo, de manera que el Altísimo se humilló hasta tomar forma de siervo, y el útero virginal de María gestó a tan gran misterio precisamente por una dispensación divina ${ }^{92}$. En otro sermón sobre la crucifixión de Cristo, San Proclo bendice a Dios por no haber dejado el cielo y no haber habitado definitivamente la vulva virginal de María, y porque, ejerciendo su poder dominador sobre la naturaleza, posee a la Virgen como templo divino ${ }^{93}$.

No muchos años más tarde San Pedro Crisólogo, en su sermón 141 sobre la encarnación de Cristo, pregunta retóricamente a los hombres si deben temerariamente considerar la concepción virginal de Cristo con ojos humanos y con sentidos corporales, y si pueden como árbitros curiosos y audaces intuir cómo las mismas manos de Dios pudieron operar para crearse para sí el templo de su propio cuerpo en el seno de la Virgen María, desvelando así el misterio escondido durante siglos y revelar el sacramento invisible para los propios ángeles ${ }^{94}$.

En esa primera mitad del siglo V, Hesiquio de Jerusalén, en su quinta homilía sobre la Virgen María, alaba a esta, destacando las figuras simbólicas con que numerosos teólogos la definen, al precisar que alguno la llamó «madre de la luz», otro «estrella de la vida», un tercero la llamó «Trono de Dios», otro la designó como «Templo más grande que el cielo», mientras alguien la llamaba «Cátedra no inferior a la cátedra de los querubines», y otro la denominaba «Huerto no sembrado, fértil, sin cultivo» ${ }^{95}$.

Uno o dos decenios más tarde, San León Magno, en su homilía 28 sobre la Natividad, asegura que, al celebrar el día del nacimiento de Jesús, pensemos en el milagroso parto de la Virgen, para creer que en ningún momento le faltó el poder del Verbo divino al cuerpo y al alma humana concebidos en ella, ni pensemos que se formó y animó primero el templo del cuerpo de Cristo, al que después le sobrevendría su habitante (el Verbo), sino que por sí mismo y en sí mismo se dio inicio a un hombre nuevo, como un único hijo, al mismo tiempo de Dios y del hombre, que tenía la naturaleza divina sin madre, y la naturaleza humana sin padre (José) ${ }^{96}$. Pues la virginidad fecundada por el Espíritu Santo dio a luz simultáneamente, sin corrupción, a una descendencia de su mismo género humano y al autor (Dios) de su linaje ${ }^{97}$.

92 «Quandonam vero caro secundum substantiam Deo immutabiliter unita est, praeterquam heri? quando sancta quidem Virgo suum uterum commodavit: Verbum autem per aurem insiliit; ac Spiritus Sanctus vivum efformavit templum; Altissimus in servi se formam exinanivit; ac demum divinae istud dispensationis mysterium uterus virginalis portavit.» (Procl.CP, Or.III.Inc.Dom., 1. M 65, 707).

93 «Benedictus Deus, quia coelum non reliquit et virginalem vulvam non definite habitavit. [...] Benedictus Deus qui dominatur in natura, et templum divinum Virginem possedit." (Procl.CP, Cruc. In: Álvarez Campos 1976, vol. IV/1, 102).

94 «Unde, o homo, his admonitus exemplis, aestima [...] utrum debeas humanis oculis, corporeis sensibus, conceptum virginis temerarius discussor adtendere; utrum possis ipsas Dei manus operantes sanctum sibi corporis templum intra alveum genetricis audax et curiosus arbiter intueri, conspectibus tuis absconditum saeculis nudare mysterium, revelare tibi ipsis angelis invisibile sacramentum». (Pet.Chrys., Serm. CXLI.Inc.Dom. ML 52, 578).

95 «Jure proculdubio omnis grati animi lingua salutat Virginem et Deiparam [...]. Iste cognominat eam, matrem lucis; ille, Stellam vitae; alius Dei Thronum appellat; alius, Templum majus coelo; alius, Cathedram non inferiorem cathedra cherubica; alius item, Hortum non seminatum, fertilem, incultum». (Hsch.H., Serm.V.Mar. Deip. M 93, 1462).

96 «Celebrantes igitur, dilectissimi, natalem diem Domini Salvatoris, partum beatae Virginis integre cogitemus, ut carni animaeque conceptae virtutem Verbi nullo temporis puncto defuisse credamus, nec prius formatum atque animatum templum corporis Christi, quod sibi superveniens vindicaret habitator, sed per ipsum et in ipso, novo homini datum esse principium: ut in uno Dei atque hominis filio, et sine matre Deitas, et sine patre esset humanitas.» (Leo Mag., Serm.XXVIII.Nat.Dom.VIII, 2. ML 54, 222).

97 «Simul enim per Spiritum sanctum fecundata virginitas, sine corruptionis vestigio edidit et sui generis sobolem, et suae stirpis auctorem.» (Ibid.). 
Hacia fines del siglo V o inicios del VI, Jacob de Sarug, en una homilía sobre la Natividad destaca la actitud obediente de la Virgen María en el momento de la Anunciación con estos poéticos términos:

Vertió en la lámpara el óleo de las buenas obras, y un gran esplendor brilló en el templo de su cuerpo.

Ardiendo quemó los aromas de las oraciones,

Para que la pura llama de su fe pura se encendiese ${ }^{98}$.

Y en otro sermón en alabanza a la Virgen, el Sarugense la ensalza así:

Feliz tú, a quien recibió, limpió y purificó el Espíritu Santo,

Y a quien hizo templo en el que el Señor del cielo se albergó como en una mansión.

[...] Feliz tú, en cuyo pequeño seno habitó sin ornato

El Gran Ser con quien se llenaron los cielos que son más pequeños que él mismo ${ }^{99}$.

En el año 567 Teodosio de Alejandría, en su importante opúsculo sobre la Asunción de María al cielo, dice que Jesús, nada más descender del cielo entre ángeles para resucitar a su madre María y llevarla al cielo, clamó sobre su sepulcro:

Levántate de tu féretro, cuerpo santo, que fuiste templo para mí: retoma esta alma que fue todos los días tabernáculo para mí. Lavántate, cuerpo mortal por naturaleza: toma tu alma inmortal, para que también tú seas completamente inmortal y te lleve al lugar de los vivos [el cielo $]^{100}$.

En ese siglo VI, Leoncio de Jerusalén, en su libro IV contra los nestorianos, expone que el Verbo Hijo de Dios fue engendrado de Dios Padre desde la eternidad en unión substancial inmutable, perfecta, indivisible y completa con Él, y luego fue concebido (en el vientre de María) por obra del Espíritu Santo de manera incorruptible y sobrenatural, sin comercio carnal; de tal forma se unieron en una sola persona el ser perfecto desde la eternidad y el formado con miembros corporales en el casto útero de la Virgen inmaculada, templo y tabernáculo del Verbo, al asumir únicamente de la Virgen en un instante carne humana perfecta y plenamente apropiada para $\mathrm{El}^{101}$.

98 «Oleum operum bonorum in lampade infudit, et magnus splendor colluxit in corporis sui templo.

Ardens cremavit precum odores,

ut pura fidei suae flamma esset incensus.» (Iac.Serug., Hom.Dom.Nat. In: Álvarez Campos 1981, vol. V, 68).

99 «Beata, quam Spiritus accepit, detersit, mundavit,

templum fecit quo coeli Dominus ut in mansione devertit.

[...] Beata, in cuius parvo gremio habitavit non ornato

ille Magnus quo pleni sunt caeli prae ipso minores.» (Iac.Serug., Hom.Virg.Mar. In: Álvarez Campos 1981, vol. V, 23).

100 «Deinde super sepulcro clamavit: "Surge a lecto, corpus sanctum, quod mihi templo fuisti: sume animam hanc quae mihi quotidie fuit tabernaculo. Surge, mortale natura corpus: animam tuam sume immortalem; ut tu quoque sis immortale totum et te in loco viventium assumam".» (Thds.Al., Serm.Assum.Mar. In: Álvarez Campos 1981, vol. V, 199).

101 «Nihil enim aliud quid secundum aeternum, et immutabile, et perfectum, et inconversibile; et indivisum, et completum, et immotum primae scilicet ejus generationis genitum est; nec secundum secundam aliud quid sic sine semine, et sine corruptione, et supernaturaliter genitum est, et Spiritu sancto conceptum, et sine tempore perfectum, et formatum, et membris instructum, et in omnem suam substantialem rationem aptatum, in casto utero immaculatae, in templum et in tabernaculum Verbi, perfecta et ipsi coaptata humana carne ex Virgine sola in uno temporis articulo.» (Leont.H., Nest.Lib.IV, 9. M 86-1, 1670). 
Hacia fines de la misma sexta centuria San Venancio Fortunato, en un pasaje de su segundo sermón sobre la Presentación de María al templo se refiere a la Madre de Dios en estos líricos términos:

Los templos del Creador son los púdicos miembros de la doncella [María], Y habita el proprio Dios tal morada.

¡Cuánto puede por su virginidad agradar la esposa,

Esa misma a quien, siendo madre, no agrada sino como virgen!102

En las décadas iniciales del siglo VIII, San Germán de Constantinopla, en su segunda homilía sobre la Presentación de María, se pregunta cómo la Virgen es presentada hoy por sus padres al templo mediante los sacerdotes, y cómo es posible que sea colocada en un templo inerte (de materia muerta) aquella que es el propio templo vivo de Dios ${ }^{103}$.

En la primera mitad del siglo VIII San Andrés de Creta, en un sermón sobre la Anunciación, ensalza a la Virgen denominándola «magnífico templo de la divina gloria», «palacio del Rey de la construcción sagrada», «tálamo en el que Cristo desposó la naturaleza humana con su naturaleza divina» ${ }^{104}$. Más o menos por las mismas fechas San Juan Damasceno, en su primera homilía sobre el Nacimiento de María, expresa que el vientre de la Virgen es el domicilio de Aquel que ningún espacio puede contener, y que María es por completo el tálamo del Espíritu Santo, la entera ciudad del Dios vivo, a la que alegran los torrentes de las gracias del Espíritu divino, la totalmente hermosa, la del todo cercana a Dios, la cual es superior a los querubines y los serafines, pues existe junto a Dios ${ }^{105}$. Y en otro pasaje de ese mismo sermón, el Damasceno proclama:

¡Oh Virgen, rebosante de las gracias divinas, templo santo de Dios, en el que el espiritual Salomón [Jesucristo], príncipe de la paz, habitó después de construirlo por sí mismo: templo, digo, no decorado con oro y piedras inertes, sino refulgente con el oro del Espíritu Santo, y conteniendo a Cristo, hermosísima perla, en lugar de piedras preciosas ${ }^{106}$.

A mediados del siglo VIII, San Juan de Eubea, en un discurso sobre la concepción de María, asegura que sus padres, Joaquín y Ana, la llevaron al templo a los tres años de edad para presentarla «como a la esposa de la indivisa Trinidad, y como un tálamo

102 «Templa Creatoris sunt membra pudica puellae, / Et habitat proprius tale cubile Deus, / Quantum sponsa potest de virginitate placere, / Ipsa cui genetrix non nisi virgo placet.» (Ven.Fort., Misc.Lib.VIII.Mar.virgin. ML 88, 268-269)

103 «quomodo, inquam, sacratissima Virgo a suis hodie parentibus per sacerdotes in templo praesentetur, quomodo animatum Domini templum, in templo inanimi collocetur». (Germ.CP, Praes.Deip.Serm.II. M 98, 311).

104 «Ave, vere benedicta, ave, illustris, ave, magnificum divinae gloriae templum: avesis, molitionis sacrae Regis palatium: ave, thalame, in quo Christus humanam sibi naturam desponsavit». (Andr.Cret., Orat.V.Annun. M 97, 894-895).

105 «Venter ejus domicilium, quem nullus locus capit. [...] Tota thalamus Spiritus, tota civitas Dei vivi, quam laetificant fluminis impetus; sancti, inquam, Spiritus gratiarum fluctus. Tota pulchra, tota Deo propinqua: haec enim Cherubim superans, et super Seraphim evecta, proxima Deo exstitit.” (Io.D, Hom.I.Natiu.M., 9. M 96, 675).

106 «O Virgo divinis gratiis affluens, templum Dei sanctum, quod spiritualis Salomon, ille princeps pacis abs se constructum inhabitavit: templum, inquam, non auro et inanimis lapidibus decoratum, sed auri loco Spiritu fulgens: pro lapidibus pretiosis, pulcherrimam margaritam habens Christum».(Ibid. 678). 
inmaculado», y la ofrecieron a Dios como un verdadero templo y trono; $y$, con intuición profética, llevaron a la Virgen, que es el templo vivo y el trono querúbico de Dios, hasta aquel templo del Señor edificado con piedras ${ }^{107}$.

Hacia mediados del siglo IX, San José el Himnógrafo asegura en uno de sus escritos marianos que la Virgen fue convertida en templo santo de Dios, quien habitó en ella de modo inefable ${ }^{108}$. En otro texto apologético el mismo vate reitera la tesis de que la inmaculada María fue hecha templo de Dios, en el que, habitando este como sacerdote, deificó la naturaleza humana, y convirtió a los creyentes en templos suyos ${ }^{109}$. Y en otro opúsculo, tras expresar sobre María que «El Espíritu Santo descendiendo sobre ti, sagrario puro de la virginidad, te convirtió en espléndido y santísimo tabernáculo de tu excelso Hijo ${ }^{110}$, en otro pasaje el mismo autor concluye que llamamos y alabamos a María como «arca contenedora del maná, y urna y candelabro, e incensario de carbón inmaterial», «trono del Señor», «candelabro espiritual, lucidísimo tálamo de Dios, tabernáculo manifiesto de la gloria; arca, urna, $\mathrm{y}$ altar» ${ }^{111}$.

Hacia mediados del siglo XI, San Pedro Damián, en un sermón sobre el Nacimiento de María, afirma que hoy nació la esplendidisima Virgen de la que procedió, como sale el esposo de su tálamo, el más hermoso de todos los hijos de los hombres, y nació del vientre de su madre (Ana) aquella que mereció convertirse en templo de la divinidad ${ }^{112}$.

En la segunda mitad de ese mismo siglo San Anselmo, en uno de sus escritos mariológicos, alaba a la Virgen María como «salón regio de la propiciación universal, causa de la reconciliación general, vaso y templo de la vida y la salvación de la Humanidad», antes de declararse incompetente para pasar en revista todos los beneficios otorgados por ella a él mismo y al mundo entero, que la aclama como su señora' ${ }^{113}$.

Hacia los primeros decenios de la siguiente centuria Geoffroi de Vendôme reitera en un sermón sobre la Natividad que la Virgen María, digna de Dios, es llamada «casa del Señor», cuya puerta oriental siempre estuvo cerrada, y con plena justicia se

107 «En palam igitur sacrificium Triadi offerentes Mariam, Annam, et Joachimum. Cum enim edita in lucem fuisset puella, atque aetate progrederetur, obtulerunt eam non quidem bimulam, nec item quatrimam, sed trimulam tanquam indivisae Trinitatis sponsam, et thalamum immaculatum. Communi praeterea voto ipsum adduxerunt, tanquam quae utrumque futura erat, ac primo quidem donum oblata Deo est, deinde vero et (tanquam) templum et thronus. Prophetico igitur spiritu Virginem in templo Domini obtulerunt. O rem plane miram! In templum lapidibus exaedificatum affertur animatum templum et thronus Cherubicus.» (Io.Eub., Conc.Deip. M 96, 1482).

108 «Templum sanctificatum Dei, qui in te habitavit, modo ineffabili, facta es, o Virgo.» (Ios.Hymn., Mar.Theot.Par. Graec. M 105, 1279).

109 «Templum Dei facta es, o summe immaculata, in quo cum ille tamquam sacerdos inhabitasset, humanam substantiam deificavit, et fideles templa sua mirabiliter effecit.» (Ibid., 1327).

110 «Spiritus sanctus in te purum virginitatis sacrarium descendens, efficit splendidum, et sanctissimum tabernaculum Filii excelsi, beatisssima.» (Ios.Hymn., Mar.Theot.Virg.Deip. M 105, 1408).

111 «Te portam imperviam, et agrum a cultura immunem; et arcam manna continens et urnam, et candelabrum, et immaterialis carbonis turibulum nominamus, o pura. Virginem solam parientem, et vulvam incorruptam servantem : thronum Domini, portam, et montem ; spiritale candelabrum, thalamum Dei lucidissimum, tabernaculum gloriae manifeste ; arcam, urnam, et mensam, te laudamus, o casta.» (Ibid., 1398).

112 «Hodie nata est splendidissima illa virgo, ex qua processit speciosus forma prae filiis hominum tamquam sponsus de thalamo suo (Psal. XLIV). Hodie prodiit ex utero matris, quae templum fieri meruit divinitatis.» (Pet.Dam., Serm.XLVI.Natiu.M. ML 144, 753.

113 «Tu aula universalis propitiationis, causa generalis reconciliationis, vas et templum vitae et salutis universorum, nimium contraho merita tua, cum in me homunculo vili singulariter recenseo beneficia tua, quae mundus amans gaudet, gaudens clamat esse sua.» (Anselm., Orat.7.Orat.Mar.amor. In: Obras completas de San Anselmo, Vol. II, Madrid, La Editorial Católica, Col. BAC, 1953, 316). 
denomina a María con el nombre de casa, es decir, templo de Dios, pues Dios mismo habitó en ella tanto por la santificación del Espíritu Santo como por la concepción humana ${ }^{114}$.

Algunos años más tarde San Bernardo de Claraval se suma también a quienes identifican el templum Dei con el vientre virginal de María, cuando en su primer sermón sobre la Natividad de Jesús expresa:

¡Oh nacimiento colmado de santidad, honorable para el mundo, querido por la humanidad [...], y admirable en todos los órdenes por la singular excelencia de su novedad, por cuanto nunca se vio ni antes ni después nada parecido! ¡Oh alumbramiento único sin dolor, el único puro e incorruptible, el único que no viola, sino que consagra el templo del seno virginal! ¡Oh nacimiento que está por encima de la naturaleza, pero que la favorece; que supera la excelencia de lo milagroso, pero que repara por el poder de su misterio! ${ }^{115}$

Tal vez por los mismos lustros Honoré d'Autun asume una postura análoga, al explicar dos citas bíblicas - «Quien me creó descansó en mi tabernáculo», y «En el sol puso su tabernáculo»- en el sentido de que «el Tabernáculo de la Iglesia o de Dios es la beata siempre Virgen María [...], en quien el Hijo de Dios haciendose hombre descansó, y de quien sale como sale el esposo de su talamo»» ${ }^{116}$.

Más de un siglo después San Buenaventura reitera similar identificación María=templo de Dios, cuando, en su cuarto sermón sobre la Anunciación, interpreta algunas citas bíblicas en clara proyección mariológica:

Así pues, diga en primer lugar la Virgen María: El que me creó, etc., porque se le ajusta al pie de la letra; pues el mismo Señor de la Majestad se descansó en su tabernáculo, al hacerse hombre en su vientre; por lo cual dice el más eximio de los profetas: El Altísimo santificó su tabernáculo. Santificó, ciertamente, por la gracia el tabernáculo que había fabricado al formar una naturaleza [humana], para poder nacer de ella. De ahí que el mismo Profeta dice en otro lugar: Un hombre ha nacido en ella, y el mismo Altísimo la fundó. Ciertamente la fundó, es decir, la confirmó en gracia, para poder establecerse firmemente en ella ${ }^{117}$.

114 «Honorabilis et praedicabilis femina, digna Deo virgo Maria domus Domini appellatur, in qua porta orientalis clausa semper esse perhibetur. Recto nomine Maria, domus, id est templum Domini dicitur, quia Deus ipse habitavit in ea, et per sanctificationem Spiritus, et per humanam conceptionem. Servata itaque divinae proprietate naturae, in utero virginis factus est caro, et perfectus homo in veritate carnis et animae, et per portam templi quae respicit ad Orientem, quae nec per se patuit, nec ab alio aperta fuit, processit de virgine matre.» (Godef.Vind., Serm.IV.Natiu.IV. ML 157, 249).

115 «O nativitas illibata sanctitate, honorabilis mundo, amabilis hominibus [...], et in his omnibus admirabilis singulari excellentia novitatis, utpote quae nec primam similem visa est nec habere sequentem! O partus solus sine dolore, solus nescius pudoris, corruptionis ignarus, non reserans, sed consecrans virginalis uteri templum! O nativitas supra naturam, sed pro natura; miraculi excellentia superans, sed reparans virtute mysterii!» (Bern., Vigil.Natiu.Serm.I, 1. In: Obras completas de San Bernardo. Edición bilingüe, Vol. III. Sermones litúrgicos $\left(1^{\circ}\right)$, Madrid, La Editorial Católica, Col. BAC, 1985, 126-129).

116 «Quae congratulando subjungit: Qui me creavit in tabernaculo meo requievit. Tabernaculum Ecclesiae vel Dei est beata semper virgo Maria, ut dicitur: In sole posuit tabernaculum suum (Psal, XVIII, 6). In quo Filius Dei homo veniens requievit, et de quo ut sponsus de thalamo processit (ibid.).» (Honor.Aug., Sig.Mar.Cant.Cant. . ML 172, 498).

117 «Primo ergo dicat Virgo Maria: Qui creavit me etc., quoniam ei competit ad litteram; ipse enim Dominus Maiestatis requievit in eius tabernaculo, dum homo factus est in eius utero; propter quod dicit eximius Prophetarum: Sanctificavit tabernaculum suum Altissimus. Sanctificavit utique per gratiam tabernaculum, quod 
Tal como este epígrafe pone de relieve, desde el siglo IV y durante un milenio se fue constituyendo con rapidez entre los Padres de la Iglesia y los teólogos medievales, tanto latinos como greco-orientales, una sólida y concordante tradición doctrinal, conforme a la cual la figura analógica del templum Dei referida en los textos canónicos se identifica directamente con la Virgen María (y/o con su vientre) y, en forma indirecta, con el cuerpo humano del Hijo de Dios concebido y encarnado en su seno virginal.

\section{Conclusiones}

El vasto análisis bidireccional de imágenes pictóricas y textos doctrinales que hemos hecho hasta aquí nos permite sintetizar los siguientes resultados:

El restringido examen de doce cuadros de tema mariano de los siglos XIV y XV revela que artistas de sensibilidad y formación tan distintas como Pietro Lorenzetti, Paolo di Giovanni Fei, Govanni Bellini, Jan van Eyck, Rogier van der Weyden, Lluís Dalmau, Piero della Francesca, Jacquemart de Hesdin y el Maestro de Boucicaut, interpretando temas tan diferentes, como el Nacimiento de María, la Anunciación, la Virgen con el Niño o la Sacra Conversazione, coinciden todos en incluir como elemento destacable en sus escenas un templo, representado a veces taxativamente en su estructura íntegra o, metonímicamente, mediante alguna de sus partes características.

Sorprende sobremanera constatar que esa representación completa o fragmentaria de un templo en imágenes marianas de este período pasa desapercibida por completo a la mayoría de los comentaristas de tales obras pictóricas, mientras algunos investigadores aluden superficialmente a ella para considerarla como un mero elemento escenográfico o decorativo, carente de significado conceptual. Muy contados son los especialistas, como Erwin Panofsky, Marilyn Aronberg Lavin y Till-Holger Borchert, que se aventuran a explicar - por desgracia, sin argumentos doctrinalesese templo pintado como figura simbólica de María como Ecclesia, es decir, como la Iglesia institucional.

En franco contraste con ese inexplicable silencio de casi todos los especialistas y esas injustificadas «interpretaciones» de algunos expertos, las numerosas citas exegéticas que hemos trasegado en los textos de muchos Padres, Doctores de la Iglesia y teólogos greco-orientales y latinos proporcionan con meridiana claridad las claves pertinentes para interpretar esa figura del templo en imágenes marianas.

En ese orden de ideas, los numerosos autores eclesiásticos que hemos examinado apuntan en dos proyecciones exegéticas algo diferentes, aun cuando interrelacionadas en su esencia. En efecto, casi todos los Padres y teólogos -entre ellos, San Zenón, San Ambrosio, San Máximo, Jacog de Sarug, Teodosio de Alejandría, Leoncio de Jerusalén, San Venancio Fortunato, San Andrés de Creta, San Juan Damasceno, San Juan de Eubea, San José el Himnógrafo, San Pedro Damián, San Anselmo, Geoffroi de Vendôme, San Bernardo, Honoré d'Autun y San Buenaventura- plantean al unísono una interpretación de marcada orientación mariológica, según la cual el refe-

fabricaverat formando naturam, ut posset nasci ex ea. Unde alibi idem Propheta: Homo natus est in ea, et ipse fundavit eam Altissimus. Fundavit utique, hoc est, in gratia confirmavit, ut firmiter posset in ea quiescere.» (Bonav., II.Annun.Serm.IV. In: Obras de San Buenaventura. Edición bilingüe, vol, IV, Teología mística, Madrid, Biblioteca de Autores Cristianos, 1963, 627). 
rido templum Dei mencionado en los textos canónicos se identifica con María como totalidad hipostática y/o con su virginal vientre, como órgano en el que se verifica la concepción/encarnación del Hijo de Dios hecho hombre.

Otros pocos escritores sacros, como San Jerónimo y San León Magno, prefieren una explicación más focalizadamente cristológica, al sostener que ese templum Dei es el cuerpo humano que el propio Hijo de Dios se construyó en el virginal seno de María para poder encarnarse como hombre.

A su vez, San Cirilo de Alejandría y San Proclo de Constantinopla, conscientes de que ambos énfasis, mariológico y cristológico, lejos de contradecirse, se complementan y completan entre sí, unifican armoniosamente ambas interpretaciones: a juicio de esos dos exégetas, el concepto «templo de Dios» constituye una ilustrativa metáfora doble, que identifica simbólicamente tanto a María (y, en particular, su vientre virginal) como al cuerpo humano que el Hijo de Dios recibió en el seno de aquella al encarnarse.

Sea cual sea el énfasis con que se formulen, esas variantes exegéticas de los Padres y teólogos se condensan y armonizan en una tesis ambivalente, al propio tiempo cristológica y mariológica, a saber: para que Dios Hijo pudiera fabricarse el «templo» de su propio cuerpo humano en el vientre de María, era necesario que primero fabricase el «templo» de la Virgen, en cuya virginal entraña sería Él concebido y recibiría su cuerpo y naturaleza de hombre. Solo tras ser construido el primer templum Dei (María), en el que habría de instalarse durante nueve meses el Hijo de Dios, podría fabricarse el segundo templum Dei (el cuerpo humano de Cristo), en el que la persona única de Dios Hijo encarnado residiría definitivamente, tras asumir su segunda naturaleza, la humana.

Por otra parte, el análisis comparativo de las doce imágenes marianas de Italia, Flandes, Francia y España de los siglos XIV y XV que hemos estudiado permite constatar que algunos artistas y/o sus probables programadores iconográficos creyeron necesario incluir en la escena pintada la estructura íntegra o parcial de un templo. De hecho, en perfecta sintonía con la concordante tradición patrística y teológica, ese templo pintado en algunas representaciones de la Virgen durante las dos referidas centurias ilustra visualmente por partida doble el templum Dei, es decir, el templo que Dios Hijo se construyó para sí mismo en María con el fin de construirse en su vientre el sagrado templo de su propio cuerpo humano, al hacerse hombre para redimir a la Humanidad.

Por tales motivos, ese templo pintado en escenas marianas de los siglos XIV y $\mathrm{XV}$ constituye una convincente metáfora plástica que permite visualizar la metáfora textual de la encarnación del Hijo de Dios en el seno de la Virgen, o, dicho de otro modo, un ilustrativo símbolo visual de la virginal maternidad divina de María.

\section{Fuentes y bibliografía}

\subsection{Fuentes}

S. Álvarez Campos (comp.), Corpus Marianum Patristicum, Burgos, Ediciones Aldecoa, 1970-1981, 7 vols.

S. Ambrosius Mediolanensis, Epistola XXX, 3. ML 16, 1062.

S. Ambrosius Mediolanensis, Epistola LXIII, 33. ML 16, 1249-1250. 
S. Andreas Cretensis, Oratio V. In sanctissimae Deiparae Dominae nostrae Annuntiationem. M 97, 894-895.

S. Anselmus Cantauriensis, Obras completas de San Anselmo. Vol. II, Madrid, La Editorial Católica, Col. BAC, 1953.

S. Anselmus Cantauriensis, Oratio ad Sanctam Mariam pro impetrando eius et Christi amore. In: Obras completas de San Anselmo, op.cit., 1953, 316.

S. Bernardus Claraevallensis, Obras completas de San Bernardo. Edición bilingüe. Promovida por la Conferencia Regional Española de Abades Cistercienses. Vol. III. Sermones litúrgicos $\left(1^{\circ}\right)$, Madrid, La Editorial Católica, Col. BAC, 1985.

S. Bernardus Claraevallensis, In Vigilia Nativitatis Domini. Sermo Primus, 1. In: Obras completas de San Bernardo. Edición bilingüe, op. cit., 1985, 126-129.

Biblia Sacra iuxta Vulgatam Clementinam. Nova editio, Madrid, La Editorial Católica, Col. Biblioteca de Autores Cristianos, 2005 $12,1.255$ p.

S. Buenaventura, Obras de San Buenaventura. Edición bilingüe, vol, IV, Teología mística, Madrid, BAC, 1963, 787 p.

S. Bonaventura de Balneoregio, II. De Annuntiatione B. Virginis Mariae. Sermo IV. In: Obras de San Buenaventura. Edición bilingüe, vol, IV, Teología mística, op.cit., 627.

S. Cyrillus Alexandrinus, In Malachiam 2, 32. M 72, 332.

S. Cyrillus Alexandrinus, Commentarius in S. Joannis Evangelium. Liber Quartus, IV, 3. M $73,615$.

S. Cyrillus Alexandrinus, De incarnatione Domini 23. M 75, 1459-1462.

S. Cyrillus Alexandrinus, Homilia Paschalis VIII, 6. M 77, 574.

S. Germanus Constantinopolitanus, In praesentationem SS. Deiparae.Sermo II. M 98, 311.

Godefridus Vindobonensis, Sermo IV. In Nativitate Domini IV. ML 157, 249.

Hesychius Hierosolymitanus, Sermo V. De sancta Maria Deipara Homilia. M 93, 1462.

S. Hieronymus Stridonensis, In Ionam 2. ML 25, 1136.

Honorius Augustodunensis, Sigillum Beatae Mariae ubi exponuntur Cantica Canticorum. ML 172, 495-518.

Iacobus Sarugensis, Homilia de Domini Nativitate. In: S. Álvarez Campos (comp.), Corpus Marianum Patristicum, Burgos, Aldecoa, 1981, vol. V, 68.

Iacobus Sarugensis, Homilia de beata Virgine Matre Dei Maria. In: Álvarez Campos 1981, vol. V, 23.

S. Iohannes Euboaensis, Sermo in Conceptionem Sanctae Deiparae, XIV. M 96, 1482.

S. Iohannes Damascenus, Homilia I In Nativitatem B.V. Mariae, 9. M 96, 675-678.

S. Iosephus Hymnographus, Mariale. Theotocia Ex Paracletica Graecorum. M 105, 12791327.

S. Iosephus Hymnographus, Mariale. Theotocia Sive Allocutiones ad beatam Virginem Deiparam. M 105, 1398-1408.

S. Leo I Magnus, Sermo XXVIII. In Nativitate Domini VIII, 2. ML 54, 222.

Leontius Hierosolymitanus, Adversus Nestorianos. Liber IV, 9. M 86-1, 1670.

S. Maximus Taurinensis, Sermo 2, 3. ML 57, 236.

J-P. Migne (ed.), Patrologiae Cursus Completus, Series Graeca, Paris, Garnier, 1857-1867, 166 vols. Citado con la abreviatura $\mathrm{M}$.

J-P. Migne (ed.), Patrologiae Cursus Completus. Series Latina, Paris, Garnier, 1844-1864, 221 vols. Citado con la abreviatura ML.

S. Petrus Chrysologus, Sermo CXLI. De Incarnatione Domini. ML 52, 578.

S. Petrus Damianus, Sermo XLVI. Homilia in Nativitate Beatissimae Virginis Mariae. ML $144,748-761$. 
S. Proclus Constantinopolitanus, Oratio I. Laudatio in sanctissimam Dei genitricem Mariam. M 65,679-691.

S. Proclus Constantinopolitanus, Oratio III. De Incarnatione Domini nostri Iesu Christi. M 65, 703-707.

S. Proclus Constantinopolitanus, Homilia 29, in crucifixionem. In: Álvarez Campos 1976, vol. IV/1, 102.

A. de Santos Otero, Los Evangelios Apócrifos, Salamanca, La Editorial Católica, Col. BAC, $148,2006,705 \mathrm{p}$.

Theodosius Alexandrinus, Sermo quem dixit Pater noster ter beatus Abbas Theodosius, archiepiscopus Alexandriae.. Omnibus Assumptionem exposuit Dominae nostre, Dei Matris, sanctae Marie.... In: Álvarez Campos 1981, vol. V, 199.

S. Venantius Fortunatus, Miscelanea. Liber VIII. In nomine Domini nostri Iesu Christi et Domnae Mariae Matris eius de virginitate. ML 88, 268-269.

S. Zeno Veronensis, Tractatuum Sancti Zenonis episcopi veronensis Liber Secundus. Tractatus VIII. De Nativitate Domini II. ML 11, 413-415.

\subsection{Bibliografía}

A. Angelini, Piero della Francesca, Firenze, Scala, 1991, 79 p.

E. Battisti, Piero della Francesca, Milano, Electa, 1992, 2 vols.

C. Bertelli \& A. Paolucci, Piero della Francesca e le corti italiane, Milano, Skira, 2007, 274 p.

T.-H. Borchert, Van Eyck, Köln, Taschen, 2008, 96 p.

T.-H. Borchert (dir.), Le siècle de Van Eyck. Le monde méditerranéen et les primitifs flamands: 1430-1530, Gand / Amsterdam, Ludion, 2002a, 280 p.

T.-H. Borchert (2002b), «Introduction: l'influence de Jan van Eyck et de son atelier», in: Borchert 2002a, 9-31.

L. Bréhier, L'art chrétien. Son développement iconographique des origines à nos jours, París, Librairie Renouard-H. Laurens éditeur, 1928, 480 p.

M. W. Brockwell, The Van Eyck problem, Westport, Greenwood Press, 1971, 102 p.

D. A. Brown and S. Ferino-Pagden, Bellini, Giorgione, Titian, and the Renaissance of Venetian painting (cat. exp.), Washington, National Gallery of Art, 2006, xv,336 p.

A. Busignani, Piero della Francesca, Firenze, Sadea, Sansoni, 1967, 120 p.

L. Campbell (ed.), Rogier van der Weyden y los reinos de la Península Ibérica (cat. exp.), Madrid, Museo Nacional del Prado, 2015, 189 p.

C. Campbell \& J.A. Chong (dir.), Bellini and The East, Boston, Yale University Press, 2005, $144 \mathrm{p}$.

L. Campbell, J. Van der Stock, Rogier van der Weyden 1400-1464. Master of passions [cat. exp.], Zwolle, Waanders / Leuven, Davidsfonds, 2009, 592 p.

É. Cammaerts, Les Bellini. Étude critique, Paris, Henri Laurens, 1912, 128 p.

G. Centauro, Dipinti murali di Piero della Francesca. La basilica di S. Francesco ad Arezzo. Indagini su sette secoli, Milano, Electa, 1990, 317 p.

A. Châtelet, Jean Van Eyck enlumineur. Les «Heures de Turin» et de «Milan-Turin», Strasbourg, Presses Universitaires de Strasbourg, 1993, 212 p.

A. Châtelet, Rogier van der Weyden (Rogier de la Pasture), Paris, Gallimard, 1999a, 146 p.

A. Châtelet, Rogier van der Weyden. Problèmes de la vie et de l'oeuvre, Strasbourg, Presses Universitaires de Strasbourg, 1999b, 301 p.

K. Clark, Piero della Francesca, London, Phaidon, 1951, 212 p. 
K. Clark, Piero della Francesca. Complete Edition, London, Phaidon, 1969, 239 p.

B. Cole, Sienese painting. From its origins to the fifteenth century, New York, Icon Editions, Harper \& Row, 1980, 243 p.

E. Daffra, «Urbino e Piero della Francesca», in: C. Bertelli \& A. Paolucci 2007, 52-67.

H. Damisch, Un souvenir d'enfance par Piero della Francesca, Paris, Seuil, 1997,183 p.

M. Davis, Rogier van der Weyden. Essai accompagné d'un catalogue critique des oeuvres qui lui ont été attribuées ainsi qu'à Robert Campin, Bruxelles, Arcade, 1973, 344 p.

O. Delenda, Rogier van der Weyden (Roger de La Pasture), Paris, Cerf, 1987, 110 p.

P. de Vecchi, The complete paintings of Piero della Francesca (introduction by Peter Murray), London, Weidenfeld and Nicolson, 1970, $111 \mathrm{p}$.

D. De Vos, Rogier van der Weyden. L'œuvre complet, Paris, Hazan, 1999, 445 p.

D. De Vos, Les primitifs flamands. Les chefs d'œuvre, (Brujas), Fonds Mercator, 2002, 216 p.

E. Dhanens, Van Eyck. The Ghent altarpiece, London, Allen Lane, 1973, 154 p.

E. Dhanens, Hubert and Jan van Eyck, New York, Tabard Press, 1980, 334 p.

É. Dhanens \& J. Dijkstra, Rogier de le (sic) Pasture van der Weyden. Introduction à l'œuvre. Relecture des sources, Tournai, La Renaissance du Libre, 1999, 205 p.

G. T. Faggin, L'opera completa dei Van Eyck, Milano, Rizzoli, 1968, 104 p.

S. Ferrari, Jan Eyck. El maestro flamenco de la luz, Barcelona, Random House Mondadori, 2005, 143 p.

B. Fransen, Rogier van der Weyden and stone sculpture in Brussels, London, Harvey Miller Publishers, 2013, 237 p.

M.J. Friedländer, Early Netherlandish painting. From van Eyck to Bruegel, London, Phaidon Press, 1966, 425 p.

M.J. Friedländer, Early Netherlandish painting. Vol. 1, The van Eycks-Petrus Christus, Leyden, A.W. Sijthoff, 1967a, 117 p.

M. J. Friedländer, Early Netherlandish painting. Vol. 2, Rogier van der Weyden and the Master of Flemalle, Leyden, A.W. Sijthoff, 1967b, 114 p.+114 p. de lam.

E. Garrison, Early Italian painting. Selected studies, vol. I: Panels and frescoes; vol. II, Manuscripts, London, Pindar Press, 1984, 2 vols.

C. Ginzburg, Indagini su Piero. Il Battesimo, il ciclo di Arezzo, la flagellazione di Urbino (Nuova edizione), Torino, Giulio Einaudi, 1994, 172 p.

R. Goffen, Piety and Patronage in Renaissance Venice. Bellini, Titian and the Franciscans, New Haven, Yale University Press, 1986, xvii,285 p.

R. Goffen, Giovanni Bellini, New Haven / London, Yale University Press, 1989, 347 p.

A. Grabar, Les voies de la création en iconographie chrétienne: Antiquité et Moyen Âge, Paris, Flammarion, 1979, 341 p.

E. Hall, The Arnolfini betrothal. Medieval marriage and the enigma of Van Eyck's double portrait, Berkeley, University of California Press, 1997, xxi,180 p.

C. Harbison, Jan van Eyck. The Play of Realism, London, Reaktion Books, 1991, 228 p.

C. Harbison, La Renaissance dans les pays du nord, Paris, Flammarion, 2000, 175 p.

P. Hendy, Piero della Francesca and the Early Renaissance, London, Weidenfeld \& Nicolson, $1968,248 \mathrm{p}$.

H. Hymans, Les van Eyck. Biographie critique, Paris, Henri Laurens, Librairie Renouard, [1907?], $128 \mathrm{p}$.

S. Kemperdick \& J. Sander (ed.), The Master of Flémalle and Rogier van der Weyden (exhib. cat.), Städel Museum, Frankfurt am Main, and the Gemäldegalerie, Staatliche Museen, Berlin, Ostfildern, Hatje Cantz, 2009, 404 p. 
B. Lane, The Altar and the Altarpiece, Sacramental Themes in Early Netherlandish Painting, New York, Harper \& Row, 1984, vii,180 p.

M. A. Lavin, Piero della Francesca. The flagellation, Chicago, University of Chicago Press, 1990, $111 \mathrm{p}$.

M. A. Lavin, Piero della Francesca, New York, Phaidon, 2002, 351 p.

R. Lightbown, Piero della Francesca, New York/London, Abbeville Press, 1992, 309 p.

C. Limentani \& M. Pietrogiovanna, Retables. L'âge gothique et la Renaissance, Paris, Citadelles \& Mazenod, 2001, 419 p.

R. Longhi, Piero della Francesca, Paris, Hazan, 1989, 310 p.

M. Lucco \& G. C. F., Villa (a cura di), Giovanni Bellini, Milano, Silvana, 2008, 383 p.

H. B. J. Maginnis, Painting in the Age of Giotto: A Historical Reevaluation, Pennsylvania, Pennsylvania State University Press, 1997, xviii,217 p.

H. B. J. Maginnis, The world of the early Sienese painter, Pennsylvania, Pennsylvania State University Press, 2001, xxi, 310 p.+ ill., s.p.

É. Mâle, L'art religieux du XIII siècle en France. Étude sur les origines de l'iconographie du moyen âge et sur ses sources d'inspiration, Paris, Armand Colin, 1988 (1898), 768 p.

É. Mâle, L'art religieux du XIIe siècle en France. Étude sur les origines de l'iconographie du Moyen Âge, Paris, Armand Colin, $1966^{7}$ (1924), IV,463 p.

É. Mâle, L'art religieux de la fin du Moyen Âge en France. Étude sur l'iconographie du Moyen Âge et sur ses sources d'inspiration, Paris, A. Colin, 19957, xi,570 p.

V. Nieto Alcaide, El Descendimiento de Van der Weyden, Madrid, Tf Edit., 2003,136 p.

M. Olivari, Giovanni Bellini, Florencia, Scala, 2010, 79 p.

O. Pächt, Van Eyck and the Founders of Early Netherlandish Painting, London, Harvey Miller,1999, $223 \mathrm{p}$.

A. Paolucci, Piero della Francesca. Catalogue complet des peintures, Paris, Bordas, 1991, $159 \mathrm{p}$.

R. Pallucchini, Giovanni Bellini, Milano, Aldo Martello, 1961, 162 p.

E. Panofsky, Les primitifs flamands, Paris, Hazan, 1992, 2 vols.

T. Pignatti, L'opera completa di Giovanni Bellini, Milano, Rizzoli, 1969, 116 p.

G. Poldi \& G.C.F., Villa, Bellini a Venezia. Sette opere indagate nel loro contesto (cat. exp.), Roma, Scuderie del Quirinale, Cinisello Balsamo, Silvana, 2008, 269 p.

G. Ragionieri, Pietro e Ambrogio Lorenzetti, Firenze, Giunti, 2009.

L. Réau, Iconographie de l'art chrétien. Tome 2, Iconographie de la Bible. Part II, Nouveau Testament, Paris, Presses Universitaires de France, 1957, 769 p.

G. Robertson, Giovanni Bellini, Oxford, Clarendon Press, 1968, xxiii,171 p.

S. Ronchey, L'enigma di Piero. L'ultimo bizantino e la crociata fantasma nella rivelazione di un grande quadro, Milano, Rizzoli, 2007, 540 p.

J.M. Salvador González, «La doctrina de Jacob de Sarug sobre la conceptio per aurem como posible fuente literaria en la iconografía medieval de La Anunciación», Mirabilia Ars, $\mathrm{n}^{\circ}$ 1 (2014/2), Universitat Autònoma de Barcelona, 2014, 95-130.

J.M. Salvador González, «Per aurem intrat Christus in Mariam. Aproximación iconográfica a la conceptio per aurem en la pintura italiana del Trecento desde fuentes patrísticas y teológicas», Ilu. Revista de Ciencias de las Religiones, $\mathrm{n}^{\circ}$ 20, Universidad Complutense de Madrid, 2015, 193-230.

G. Schiller, Ikonographie der christlichen Kunst. Band 4,2, Maria, Gütersloh, Gütersloher VerlagHaus, 1980, 472 p.

L. Seidel, Jan van Eyck' Arnolfini portrait. Stories of an icon, Cambridge (UK), Cambridge University Press, 1993, 308 p. 
C. Semenzato, Giovanni Bellini, Barcelona, Toray, 1968, 39 p.+ 80 p. de lám.

A. Simpson, Van Eyck. The complete works, London, Chaucer, 2007, 128 p.

A. Smart, The Dawn of Italian Painting 1250-1400, Oxford, Phaidon, 1978, 152 p.

J. C. Smith, The Northern Renaissance, London, Phaidon Press, 2004, 447 p.

C. Stroo \& P. Syfer-d'Olne, The Flemish primitives. Catalogue of early Netherlandish painting in the Royal Museums of Fine Arts of Belgium. 1, The Master of Flémalle and Rogier van der Weyden groups, Brussels, The Museums, 1996, 275 p.

A. Tempestini, Giovanni Bellini, Milano, Electa, [2000], 195 p.

M.-L. Thérel, Le triomphe de la Vierge-Église. Sources historiques, littéraires et iconographiques, Paris, Éditions du CNRS, 1984, 374 p.

G. M. Toscano, Il pensiero cristiano nell'arte, Bergamo, Istituto Italiano d'Arti Grafiche, 1960, 3 vols.

L. van Puyvelde, La peinture flamande dès van Eyck à Metsys, Bruxelles, Meddens, 1968, $262 \mathrm{p}$.

L. Venturi, Piero della Francesca, Genève, Skira, 1990 (1954), 113 p.

C. Volpe (a cura di M. Lucco), Pietro Lorenzetti, Milano, Electa, 1989, 225 p.

C. Volpe, Pietro Lorenzetti ad Assisi, Milano, Fratelli Fabbri / Albert Skira, 1965, 40 p.

J. Wilde, La pintura veneciana. De Bellini a Ticiano, Madrid, Nerea, 1988, 294 p.

J. Yarza, Jan van Eyck, Madrid, Historia 16, 1993, 145 p.

E. Zucchetta, «Chiesa di San Zaccaria. La Pala di San Zaccaria», in: G. Poldi \& G. C. F., Villa, Bellini a Venezia, op.cit., p. 153-167.

S. Zuffi, Giovanni Bellini, Milano, Arnoldo Mondadori, 1991, 58 p. 